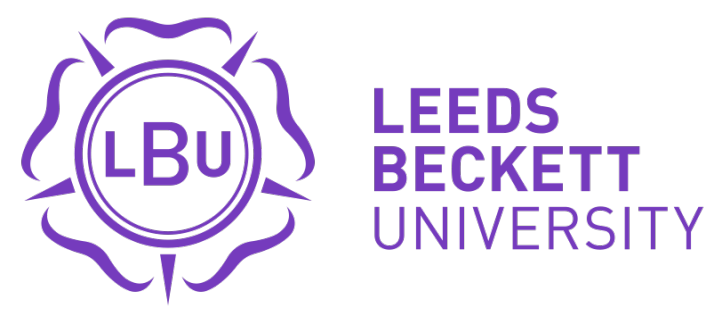

Citation:

Gifford, RM and O'Leary, T and Cobb, R and Blackadder-Weinstein, $\mathrm{J}$ and Double, $\mathrm{R}$ and Wardle, $\mathrm{S}$ and Anderson, RA and Thake, CD and Hattersley, J and Imray, C and Wilson, A and Greeves, JP and Reynolds, RM and Woods, D (2019) Female reproductive, adrenal and metabolic changes during an Antarctic traverse. Medicine and Science in Sports and Exercise, 51 (3). pp. 556-567. ISSN 1530-0315 DOI: https://doi.org/10.1249/MSS.0000000000001803

Link to Leeds Beckett Repository record:

https://eprints.leedsbeckett.ac.uk/id/eprint/5400/

Document Version:

Article (Accepted Version)

The aim of the Leeds Beckett Repository is to provide open access to our research, as required by funder policies and permitted by publishers and copyright law.

The Leeds Beckett repository holds a wide range of publications, each of which has been checked for copyright and the relevant embargo period has been applied by the Research Services team.

We operate on a standard take-down policy. If you are the author or publisher of an output and you would like it removed from the repository, please contact us and we will investigate on a case-by-case basis.

Each thesis in the repository has been cleared where necessary by the author for third party copyright. If you would like a thesis to be removed from the repository or believe there is an issue with copyright, please contact us on openaccess@leedsbeckett.ac.uk and we will investigate on a case-by-case basis. 


\section{Female reproductive, adrenal and metabolic changes during an Antarctic traverse}

Gifford RM ${ }^{1,2 *}$, O'Leary $\mathrm{T}^{3}$, Cobb R, ${ }^{4}$ Blackadder-Weinstein $\mathrm{J}^{2}$, Double $\mathrm{R}^{3}$, Wardle $\mathrm{S},{ }^{3}$

Anderson $\mathrm{RA}^{5}$, Thake $\mathrm{CD}^{6}$, Hattersley $\mathrm{J}^{7}$, Imray $\mathrm{C}^{7}$, Wilson $\mathrm{A}^{7}$, Greeves $\mathrm{JP}^{3}$, Reynolds

$\mathrm{RM}^{1 * *}$, Woods $\mathrm{DR}^{2,8,9,10 * *}$

1 University/British Heart Foundation Centre for Cardiovascular Science, Queen's

Medical Research Institute, University of Edinburgh, Edinburgh, UK EH16 4TJ.

2 Research \& Clinical Innovation, Royal Centre for Defence Medicine, Lichfield, UK

3 Army Personnel Research Capability, Andover, UK

4 Performance, Nutrition and Dietetic Consulting, pndconsulting.co.uk

5 MRC Centre for Reproductive Health, Queen's Medical Research Institute, University of Edinburgh, Edinburgh, UK

6 Faculty of Health and Life Sciences, Coventry University, Coventry, UK

7 Human Metabolic Research Unit, Universities of Coventry and Warwickshire NHS Trust and University of Warwick, Warwick, UK

8 Research Institute for Sport, Physical Activity and Leisure, Leeds Beckett University, Leeds, UK

9 Northumbria and Newcastle NHS Trusts, Wansbeck General and Royal Victoria Infirmary, Newcastle, UK

10 University of Newcastle, Newcastle upon Tyne, UK

* Corresponding Author

${ }^{* *}$ Contributed equally as senior author

\section{Abstract}

PURPOSE: To explore the effects of the first all-female transantarctic expedition on hormonal axes pertinent to reproductive and metabolic function.

METHODS: Six females (aged 28-36, BMI $24.2 \pm 0.97 \mathrm{kgm}^{-2}$ ) hauled $80 \mathrm{~kg}$ sledges $1700 \mathrm{~km}$ in 61 days. Estimated average energy intake was 
$20.8 \pm 0.103 \mathrm{MJ} /$ day $(4970 \pm 25 \mathrm{kcal} /$ day $)$. Whole body and regional body composition was measured by DXA one and two months before, and

15 days after, the expedition. Body fat was also estimated by skinfold and bioimpedance analysis immediately before and after the expedition.

Blood tests comprised basal metabolic and endocrine markers followed by evening ingestion of $0.25 \mathrm{mg}$ dexamethasone and 1-hour, $10 \mu \mathrm{g}$ Gonadorelin and $1.0 \mu \mathrm{g} \mathrm{ACTH}-(1-$ 24) tests the following morning, 39-38 pre- and 4-5 and 15-16 days post-expedition. Cortisol was assessed before and after the expedition in hair (monthly average concentrations) and saliva (5-point day curves and two-point diurnal sampling).

RESULTS: Average body mass loss was $9.37 \pm 2.31 \mathrm{~kg}(\mathrm{p}<0.0001)$, comprising loss of fat mass only; total lean mass was maintained. Basal sex steroids, corticosteroids and metabolic markers were largely unaffected by the expedition except leptin, which decreased during the expedition and recovered after 11 days, the change being proportionately greater than change in body fat. LH reactivity was suppressed prior to and during the expedition, but recovered after 11 days, while FSH did not change during or after the expedition. Cortisol reactivity did not change during or after the expedition. Basal (suppressed) cortisol was $73.25 \pm 45.23 \mathrm{mmol} / \mathrm{L}$ before, $61.66 \pm 33.11 \mathrm{mmol} / \mathrm{L} 5$ days post- and

$54.43 \pm 28.60 \mathrm{mmol} / \mathrm{L} 16$ days post-expedition $(\mathrm{p}=0.67)$. Monthly average cortisol was elevated during the expedition.

CONCLUSION: The maintenance of reproductive function and the HPA axis in women following an extreme physical endeavor, and despite a modest energy deficiency, suggests the female biological capacity for extreme endurance exercise is greater than anticipated.

\section{Keywords}

Arduous exercise, pituitary function, adrenal function, energy deficit, female athlete triad 


\section{Introduction}

Women undertake increasingly physically demanding sports and employment but sexrelated biological consequences of arduous exercise are poorly understood. Over the past 20 years, emphasis on energy availability (EA, defined as energy intake minus exercise energy expenditure) has established low EA as a putative cause of the 'female athlete triad': hypothalamic pituitary gonad (HPG) axis suppression in athletes, leading to functional hypothalamic amenorrhoea (FHA) and/ or impaired bone health (1). The term 'female athlete triad' has been questioned, since these phenomena can also affect men (2), however women may have greater sensitivity to the effects of low EA than men, and there is a higher prevalence of disordered eating among women than men (3).

In the setting of military employment, it has been suggested that women may be at higher risk of psychological problems than men, such as post-traumatic stress disorder $(1,4)$. There appears to be evidence suggesting a greater incidence of primary infertility in military women than age-matched civilians (5). While these observations remain unexplored in terms of etiology, we recently proposed FHA in military women might contribute to menstrual dysfunction, hypothesizing this could be mediated by a complex alteration in hormonal milieu, including reduced EA (1). Aspects of military training and employment other than exercise and reduced EA may also be likely to contribute to HPG axis suppression, for example, sleep deprivation and psychological stress $(1,6,7)$.

Field studies of military training generally measure the effects of multiple concurrent stressors, making it difficult to delineate the effects of individual components like low EA, sleep deprivation or psychological stress (6). One highly researched model of the endocrine effects of a multi-stressor environment is US Army Ranger Training. Predominantly undertaken by men, Ranger training involves 61 days of strenuous exercise, sleep deprivation, total energy expenditure of around 4000-5000kCal/ day, 
routine energy deficit and widespread metabolic and hormonal deficiencies, e.g. elevated fasting cortisol, reduced total testosterone and IGF-1 $(7,8)$. Such changes have been demonstrated to be reversible upon re-feeding, cessation of stress and sleep derestriction (8). However, extremes of arduous exertion lasting this duration have not been widely researched in women.

We undertook an exploratory, observational study of the concurrent acute response and short-term recovery of female HPG and HPA axes (using basal and dynamic testing) in women undertaking an unprecedented, extremely arduous expedition to cross the Antarctic continental landmass, of similar duration to US Army Ranger training. The purpose of the crossing was to attempt to become the first all-female team to complete an unassisted Antarctic traverse using muscle power alone, and was not competitive, primarily research-focused or done to achieve a political or military training objective. The $a$ priori hypothesis was that this expedition would induce an energy deficit, despite a comprehensive programme of physical and nutritional preparation, with concurrent disturbances in HPG and HPA axes.

\section{Methods}

\section{Participants}

Six women participating in an unassisted Antarctic ski traverse expedition were invited to participate in the study three months beforehand. This was the first all-female team to attempt an unassisted Antarctic traverse. Individuals planned to haul sledges weighing $80 \mathrm{~kg}$ for $1700 \mathrm{~km}$, expecting the crossing to take around 75 days. Selection and training for the expedition lasted 2 years, the final team being selected from a pool of 250 women. While none of the participants had been to Antarctica before, all had partaken in three preparatory expeditions in Norway, which aimed to simulate the crossing's intensity and 
conditions (details can be found at http://exicemaiden.com/). Participation in the study was voluntary and independent of the expedition. All six women volunteered and provided written informed consent. Ethical approval was received form the Ministry of Defence Research Ethics Committee (827MoDREC/17). The study was conducted in accordance with the Declaration of Helsinki.

\section{Experimental design}

The study design consisted of two pre-expedition measurement sessions, 64 and 39 days prior to the expedition (visit pre-1 and pre-2, respectively) (figure 1A). Additional body composition measurements were undertaken separately from formal study visits, 16 days before and 5 days after the expedition. Follow-up visits were conducted 4 days after the expedition (immediately after arrival in Punta Arenas, Chile from Antarctica), and 15 days after the expedition, 36 hours after return to the UK (visits post- 1 and post-2 respectively). As part of a broader preparation schedule, participants were advised to gain $0.5 \mathrm{~kg}$ of body mass per week between visit pre-1 and the expedition (64 days or 9 weeks; $4.5 \mathrm{~kg}$ ). The expedition altitude profile and distance are indicated in figure 1B. The maximum elevation above sea level (ASL) was $2950 \mathrm{~m}$.

\section{Dietary provision}

Dietary provision for the expedition was estimated from changes in body mass during three training expeditions. During the expedition participants were provided with a complete diet providing average $20.9 \pm 0.1 \mathrm{MJ}$ per day $(4970 \pm 25 \mathrm{kcal}$ per day, or $70.8 \pm 0.35$ $\mathrm{kcal} / \mathrm{kg} /$ day $)$, comprising $\sim 45 \%$ carbohydrate $(7.7 \pm 0.32 \mathrm{~g} / \mathrm{kg} /$ day $), \sim 45 \%$ fat $(3.6 \pm 0.07$ $\mathrm{g} / \mathrm{kg} /$ day $)$ and $\sim 10 \%$ protein $(1.7 \pm 0.35 \mathrm{~g} / \mathrm{kg} /$ day $)$. It is estimated (verbal communication) 
that participants consumed median $85 \%$ (range $70 \%$ - $99 \%$ ) of the diet provided over the course of the expedition and did not share rations.

\section{Procedures}

The schedule of measurements is illustrated in Figure 1. At visit pre-1, information including ethnicity, education, smoking habits, alcohol consumption, and a comprehensive medical reproductive and medication history taken including use and type of, and indication for, hormonal contraceptives was recorded. Reproductive and medication history and use of contraceptive questions were repeated after the expedition (visit post-1).

\section{Psychological assessment}

Questionnaires comprising six validated self-rating items on a web-based application (SmartSurvey, Tewkesbury, UK) were completed at visits pre-2 and post-1 (figure 1). The psychosocial stress questionnaire was completed in an identical manner to Rosengren et al, assessing the sixmonth period prior to visit pre-2, and the four-month period prior to visit post-1 (9). Participants were asked to complete the Impact of Events Scale - Revised (IES-R) with reference to any major life event(s) identified (10). The Patient Health Questionnaire 9 (PHQ-9) (11) was chosen as a robust measure of depressive symptoms in military and civilian populations (12). We analyzed results on a continuous scale, to identify subtle differences in a low number of participants. The Beck Anxiety Inventory (BAI) and Connor Davidson Resilience Scale 10 (CDRISC 10) demonstrate similar consistency measuring anxiety and resilience, respectively, and were analyzed in the same manner $(13,14)$. The BEDA-Q assesses risk of disordered eating concisely and consistently,(15) and was scored according to the methods of Peric et al. (16). Total scores from each questionnaire were used for further analysis. 
During the expedition, a weekly questionnaire was completed in the same manner as previous studies of female transantarctic expedition (figure 1) $(17,18)$. This documented average perceived exertion, psychological stress, restfulness of sleep and confidence the team would complete the expedition (all on a Likert type-scale ranging from 1 [not at all] to 10 [the most possible]), and the average number of hours slept per night.

Body composition

Stature was measured at visit pre-1 (SECA Stadiometer 213, Birmingham, UK) and body mass was measured at every study visit (SECA

Scales 874 ). Whole body and regional lean mass, fat mass and bone mineral content were measured using dual energy $\mathrm{x}$-ray absorptiometry (DXA) was measured with participants wearing shorts and t-shirts at visits pre-1, pre-2 and post-2 (GE Lunar iDXA, GE Healthcare, Chalfont St Giles, UK) (figure 1).

Sixteen days prior to the expedition (separately from main study visits), and at visit post-1, skinfolds were measured at four sites (bicep, triceps, sub-scapular, supraspinatus) to the nearest $\mathrm{mm}$ by the same examiner using Harpenden calipers (BodyCare, UK) according to the method of International Society for the Advancement of Kinanthropometry (19). The average of three measurements taken from each site was used to calculate percentage body fat (19).

Body fat was measured by four-point bioimpedance (Omron BF511, Milton Keynes, UK) upon waking in the morning, 1, 5, 10, 15 and 18-24 days after the expedition. 


\section{Basal blood samples}

After an overnight fast, a venous blood sample was collected at visits pre-2, post-1 and post-2 for measurements of metabolic, nutritional, reproductive and adrenal function.

\section{Dynamic reproductive and adrenal cortex function}

Dynamic reproductive and adrenal cortex function was measured at visits pre-2, post-1 and post-2. Participants first ingested $0.25 \mathrm{mg}$ dexamethasone at $2200 \mathrm{~h}$ before a second overnight fast. This dose has been used to assess the sensitivity of the HPA axis to a nearphysiological level of central negative feedback and to attempt to reduce the baseline variation in morning fasting cortisol prior to the prestimulation test cortisol. $(20,21)$ At 0800 the following morning, a 21-gauge cannula was inserted into an antecubital or dorsal hand vein and a baseline blood sample was obtained before $10 \mu \mathrm{g}$ Gonadorelin hydrochloride (Intrapharm, Maidenhead UK), followed by $1.0 \mu \mathrm{g} \mathrm{ACTH-(1-24)} \mathrm{(tetracosactrin} \mathrm{acetate} \mathrm{as}$ Synacthen $\AA$, Mallinckrodt, Dublin, Ireland), were injected followed by a $10 \mathrm{~mL}$ saline flush. ACTH-(1-24) was freshly diluted using $249 \mathrm{ml} 0.9 \% \mathrm{NaCl}$ (Baxter, UK), to which Synacthen ® $250 \mu \mathrm{g}$ in $1 \mathrm{~mL}$ had been added, shaken thoroughly and $1 \mathrm{ml}$ of this mixture was injected using a $5 \mathrm{ml}$ syringe to minimise contact with plastic. Venous blood was sampled through the cannula in EDTA-containing tubes 20, 30, 40 and 60 min after drug administration. The doses of Gonadorelin, dexamethasone and ACTH-(1-24) were selected to mimic physiological levels of stimulation, as opposed to stimulation tests used clinically (and recommended in various clinical practice guidelines) which are intended to induce maximal axis stimulation and exclude endocrine insufficiency (e.g. $100 \mu \mathrm{g}, 1 \mathrm{mg}$ and $250 \mu \mathrm{g}$, respectively) (20). 
A $0.5 \mathrm{~cm}$ diameter hair sample was taken close to the scalp for measurement of cortisol at visit pre-2 (6x 1cm segments) and visit post-1 (4 $\mathrm{x}$

$1 \mathrm{~cm}$ segments). Hair grows at $1 \mathrm{~cm}$ per month, thus $1 \mathrm{~cm}$ represents 1 month of cortisol exposure (22).

Saliva was sampled by chewing on a synthetic swab for 1 minute, which was placed in a plastic collection tube (Salivette®; Sarstedt, Nümbrecht, Germany). A detailed saliva day curve was measured at visits pre-2 and post-2 as follows: participants were woken at 07:00 and saliva sampled at 07:10, 08:20, 09:00, 09:30, 12:15, 13:30, 17:20 and 21:50. Evening and morning saliva sampling (last thing at night before going to sleep and immediately after waking the following morning) were also measured 1, 5 and 10 days after the expedition.

\section{Laboratory methods}

Blood was collected in EDTA, serum-separating gel and fluoride oxalate tubes (Monovette®, Sarstedt, Nümbrecht, Germany) and centrifuged at 5,000 rpm for 5 minutes. Plasma and serum were stored at $-80^{\circ} \mathrm{C}$ (after dry ice shipment to the UK of samples taken in Chile) until measurement.

Metabolic and nutritional markers

Thyroid stimulating hormone (TSH), unbound thyroxine (fT4) and total T3 (tT3) were measured from gel-separated serum using Abbott ${ }^{\circledR}$

Architect analyzer (Abbott, Maidenhead, UK) according to manufacturer's instructions. Insulin-like growth factor 1 (IGF-1), ferritin, insulin and Cpeptide were determined from gelseparated serum using Roche ${ }^{\circledR}$ Cobas e411 analyzer (Roche Diagnostics, Welwyn 
Garden City, UK) according to manufacturer's instructions. Creatinine, albumin, transferrin, calcium, zinc, iron and magnesium were determined from gelseparated serum and glucose and lactate from plasma containing fluoride oxalate using commercial kits (Alpha Laboratories, Eastleigh, UK) adapted for use on a Cobas Fara centrifugal analyzer (Roche, UK). Leptin was measured by ELISA (Quantikine, USA). Urea was determined from gelseparated serum using a commercial kit (Randox laboratories, UK) adapted for use on a Cobas Fara centrifugal analyzer. Plasma pH was detected in using a blood gas analyzer (Siemens RapidLab 348EX, Camberley, UK). Homeostatic modelling assessment (HOMA) for beta cell function (HOMA-B) insulin sensitivity (HOMA-S) and insulin resistance (HOMA-IR) were calculated according to the methods of Levy et al.

Additional data including resting energy expenditure and substrate utilization from direct calorimetry pre- and post-expedition are being published elsewhere.

\section{Reproductive markers}

Luteinizing hormone (LH), follicle stimulating hormone (FSH), progesterone and estradiol were determined from plasma containing EDTA using

Abbot Architect $®$ analyzer according to the manufacturer's instructions. Inhibin B was measured by ELISA (Beckman Coulter, High Wycombe,

UK). Sex hormone binding globulin (SHBG) and anti-müllerian hormone (AMH) were determined from gel-separated serum using Roche ${ }^{\circledR}$

Cobas e411 analyzer according to manufacturer's instructions. The rationale for these methods are summarized in supplementary box 1. 
Cortisol, $17 \mathrm{OH}$ progesterone, testosterone, dihydroepiandrostenedione (DHEA) and androstenedione were measured using liquid chromatography mass spectrometry (LC/ MS), by modifying internal standards from a protocol described previously (24). Hair was divided into $1 \mathrm{~cm}$ segments and powdered prior to cortisol extraction in each segment, representing 1 month averages, for a total of 10 months. Extraction and analysis by LC/ MS was completed as described by Kirschbaum et al. (25). Saliva was stored at $-80 \mathrm{C}$ within 7 days of collection and was extracted and analyzed by LC/ MS as described by Miller et al. (26).

Inter-assay $\%$ CV was $<4 \%$ for Architect $\AA$, e411, Fara assays and blood gas analyzer, and intra-assay $\%$ CV $<10 \%$ for all ELISAs.

\section{Statistical Analysis}

Data are presented as individual data, or mean \pm SD or median (IQR) for group comparison. Normality was assessed using Shapiro-Wilk test and non-normally distributed data were log transformed prior to statistical analysis. Due to the small sample size, variables are presented as mean (95\% confidence interval [CI]). Repeated measures ANOVA was used to compare change in variables over time and pairwise comparisons were used where appropriate for statistically significant results. Paired t tests were used to compare the two pre-expedition DXA scans, and single post-expedition variables with baseline. Pre- and post-expedition dichotomous questionnaire data were compared using Chi squared test. One individual was excluded from analyses of basal reproductive hormones as she had commenced a combined contraceptive pill immediately prior to the expedition. Serum LH and FSH concentrations following injection of GnRH and ACTH were described as absolute values, and as percentage change, by dividing concentrations 
after injection by the baseline concentration. This was done to allow comparison of withinsubject change, since hormone-containing contraceptive use influenced baseline values. Area under the curve (AUC) was calculated using the trapezoidal rule. Within-subject changes in peak and AUC of cortisol and fold-rise in LH and FSH from baseline were compared from before to after the expedition.

Statistical analysis was performed using SPSS version 23.0 for Mac (IBM, USA). Significance was set at $p<0.05$. For multiple variables assessed in the same domain, Bonferroni adjustment was made as follows: body composition, $\mathrm{p}<0.01$; basal reproductive markers, $p<0.005$, adrenal markers $p<0.05$, metabolic markers, $p<0.002$.

\section{Results}

\section{Description of participants}

Baseline characteristics of the cohort are shown in table 1. The median (range) age was 32.8 (28.6 to 36.1 ) years. Baseline questionnaires demonstrated high resilience, low depression and anxiety scores and normal patterns of eating behaviour. Fasting $\mathrm{TSH}$, free T4, total T3, prolactin, LH:FSH ratio, androstenedione, total testosterone, DHEA, 17-OH progesterone, urea, sodium, potassium, chloride and creatinine were within normal limits prior to the expedition (table 2).

All participants used hormonal contraceptives during the expedition, intending to induce amenorrhoea. One individual commenced levonogestrel $150 \mathrm{mcg} /$ ethinylestradiol $30 \mathrm{mcg}$ immediately prior to the expedition. One individual used Nexplanon $\AA^{\circledR}$ contraceptive implant while all others used a Mirena ${ }^{\circledR}$ intrauterine device. Five participants were amenorrhoeic during the expedition and one menstruated twice, stating this was less frequent than normal, within 4-10 days of due date. 
Intra-expedition rating scales

Average scores for physical exertion scale were $5.5 \pm 2.3 / 10$ and stress level $3.7 \pm 1.94$ $/ 10$, and level of confidence the team would complete the expedition $6.73 \pm 1.81) / 10 ;(6.35$ \pm 1.93 in weeks $1-3$ and $7.11 \pm 1.32$ in weeks $5-8, p=0.09$ ). Average duration of sleep was $6.73 \pm 1.75$ hours and rating of restfulness of sleep was $5.53 \pm 2.05 / 10$. Questionnaires following the expedition suggested moderately lower levels of psychosocial stress and financial stress, and fewer significant adverse events than prior to the expedition $(p=0.079$, supplementary table 2).

Body composition, metabolic and nutritional changes

Physical changes during the study are presented in figure 2 and supplementary tables 1 and 2. All participants gained body mass during the two months prior to the expedition, (average increase $2.56 \pm 0.79 \mathrm{~kg}$, or $3.69 \pm 1.12 \%$ of body weight, $p=0.006$ ), consisting of body fat (average increase $4.05 \pm 0.96 \%, \mathrm{p}<0.0001$ ), and lost body mass during the expedition (average loss $9.37 \pm 2.31 \mathrm{~kg}$, or $12.9 \pm 3.17 \%$ of body weight, $\mathrm{p}<0.0001$ ). Body composition measured by DXA demonstrated a significant increase in total fat mass before $(13.2 \pm 2.11$ vs $17.5 \pm 2.52 \mathrm{~kg}, \mathrm{p}<0.001$ ) and loss during the expedition (fat mass at visit post- 2 was 12.1 $\pm 1.37 \mathrm{~kg}, \mathrm{p}<0.001$ ), with these changes reflected in most regions (supplementary table 2). However, there was no difference in total lean mass or bone mineral content between visit pre- 2 and visit post- $2(52.3 \pm 2.10$ vs $51.5 \pm 3.04, p=0.27)$, despite a $6.10 \%$ loss in lean mass from the legs. In the 15 days between the expedition and the follow-up DXA scan, fat mass estimated by bioimpedance tended to increase (supplementary table 1). Regional DXA analysis showed statistically significant but modest decreases in android (area between the ribs and pelvis), gynoid (pelvis and upper thighs) and leg lean mass between visits pre-1 
and pre-2, and loss of leg lean mass during the expedition (average $6.05 \pm 1.11 \%$ decrease), but these did not impact the change in total lean mass (supplementary table 2). There was a small but statistically significant increase in total bone mineral content prior to the expedition $(2.75 \pm 0.13 \mathrm{~kg}$ vs $2.80 \pm 0.13) \mathrm{kg}, \mathrm{p}=0.005$, but no change between visits pre- 2 and post- $2(2.77 \pm 0.12, p=0.19$ (supplementary table 2$)$.

Leptin decreased significantly following the expedition, thereafter increasing two-fold from visits post-1 to post-2 (table 2). Post-hoc tests showed the change between visit pre-2 and post-1 was significant $(p=0.005)$, while there was no difference between pre-2 and post-2 $(p=0.39)$. Thyroid stimulating hormone, free T4 and total T3 were normal pre-expedition and remained unchanged after the expedition (table 2). Fasted glucose, HOMA-B, HOMAS and HOMA-IR, adjusted calcium, magnesium and phosphate did not change during or after the expedition (table

2).

Questionnaire data demonstrated a marginal increase in BEDA-Q scores after the expedition, consistent with higher markers of disordered eating risk (supplementary table 3). Markers of nutritional status (albumin, magnesium, phosphate, iron, zinc), urea (Ln transformed) and electrolytes did not change during or after the expedition (table 2).

Reproductive function

Basal markers of reproductive function are displayed in table 2. Estradiol tended to be lower at visit post-1, with a recovery noted by visit post2. No differences between other sex steroids, $\mathrm{LH}$ or FSH were shown. Inhibin $\mathrm{B}$ and $\mathrm{AMH}$ did not differ between baseline and immediately after the expedition $(p=0.71$ and $p=0.15$, respectively, table 2$)$. 
Dynamic LH and FSH responses before and after the expedition are shown in figure 3. Fold rise in FSH and FSH AUC were log transformed prior to statistical analysis. $\mathrm{LH}$ and FSH fold rise and AUC during the test did not differ between visit pre-2 and visit post-1. At visit post-2, FSH had not changed from visit pre-1 (figure 3C, supplementary table 4), while there was a marked upward trend in $\mathrm{LH}$, measured by AUC fold rise and peak fold rise $(p=0.055$ and $p=0.071$, respectively; figure $3 D$, supplementary table 4$)$.

\section{Adrenal cortex function}

Basal plasma cortisol did not change significantly during or after the expedition (table 2).

Average hair cortisol before and during the expedition is shown in figure $4 \mathrm{~b}$. Mean values are shown in supplementary table 4. Most participants demonstrated a significant increase in average cortisol levels during the expedition.

Individuals' dynamic plasma cortisol responses before and after the expedition are shown in figures 4A. Both $A \cup C$ and peak cortisol did not change between the three time points $(p=0.12$ and $p=0.45$, respectively, figure $4 B)$. Subjects demonstrated marked suppression of early morning cortisol following low-dose dexamethasone administration

One participant demonstrated a more suppressed baseline in plasma cortisol than others (filled square symbol, figure 4). This individual also demonstrated markedly higher hair cortisol concentration through the expedition and two months beforehand.

Salivary cortisol in the days immediately following the exercise was blunted but by day 10 had recovered (figure $4 \mathrm{C}$ ), reflected in a normal day curve which was unchanged from baseline (figure 4D). 


\section{Discussion}

With on-going debate as to whether women can endure extreme physical activity without detrimental effects on hormonal axes, given the finding of HPA and HPG axis suppression in extremely arduous exercise in men (e.g. in US Army ranger training $(7,8)$ ), we exploited the opportunity to examine the HPA and HPG axes among six women who completed a $1700 \mathrm{~km}$ ski expedition hauling $80 \mathrm{~kg}$ sledges up to $2950 \mathrm{~m}$ elevation. In doing so, the team broke several records including being the first all-female team to cross the Antarctic unsupported. Our data demonstrate HPG and HPA axis resilience during extreme exertion despite significant fat loss. HPA axis basal function, sensitivity to central suppression and adrenal reactivity to ACTH did not change during or after the expedition, but demonstrated greater sensitivity to suppression from dexamethasone than anticipated from other studies using a similar protocol in older participants $(20,21)$. Hair cortisol rose during the expedition as would be expected with sustained arduous exercise (27).

Coincidentally, the expedition duration (61 days) was identical to US Army Ranger training. Trainee Rangers are expected to cover around $322 \mathrm{~km}$, carrying 30-41 kg. While the expedition comprised a different form of exercise (skiing rather than walking or running), it was arguably noninferior in terms of effort or endeavor. One crucial difference is the 0-5 hours of sleep per day expected during Ranger training,(7) and deliberate psychological stress (28). which contrasts with the average $6.73 \pm 1.75$ hours of sleep per night, albeit with poor perception of restfulness (in 24-hour daylight), and modest weekly and wholeexpedition stress ratings.

The primary drivers of adverse endocrine and metabolic changes in Ranger training appear to be nutritional deprivation (with loss of lean mass), psychological stress, sleep deprivation and exercise intensity. Nindl et al. showed a $12.6 \%$ loss of body mass, $6 \%$ lean mass and $50 \%$ fat mass $(7,28)$. The endocrine effects of negative energy balance are 
well-documented adaptations for survival and include suppression of the HPG axis and hypercortisolemia (1). In their meta-regression of field studies of arduous training, Murphy et al. showed that the combination of training duration and low EA were inversely associated with physical performance (29), although it is difficult to delineate EA as a cause from the other factors described here.

A carefully calculated provision of approximately $21 \mathrm{MJ} /$ day $(5000 \mathrm{kcal} / \mathrm{day} ; \sim 45 \%$ carbohydrate, $\sim 45 \%$ fat and $\sim 10 \%$ protein), with significant fat gain prior to the expedition, plus a relatively low altitude and preservation of sleep, meant participants lost only fat mass, not lean mass. Sustained, submaximal exertion appears to have had the effect of preserving total lean mass, although leg lean mass reduced by $6.10 \%$. This may relate to muscle fiber pennation rather than reduced mass per se; we were unable to confirm this by biopsy. Thus, weight loss was healthy, reinforcing the importance of appropriate nutrition preventing loss of lean mass and/ or hormonal disturbances, as has been shown in overtraining syndrome.(30) As insufficient nutrition has been shown to cause multiple endocrine deficiencies in sports and exercise,(2) we hypothesize that sufficient and appropriate nutrition had an important role in preventing changes to the HPA and HPG axes.

Calbet et al. demonstrated that exercise maintains lean mass, during a 4-day extreme energy deficit in overweight men (31). Protein supplementation alone $(1.5 \mathrm{~g} / \mathrm{kg}$ body mass/day) did not preserve lean mass, compared with carbohydrate. However, as demonstrated by Smith et al. in obese, sedentary women, a protein intake of $1.2 \mathrm{~g} / \mathrm{kg} / \mathrm{day}$ mitigated loss of lean mass, compared with low protein intake $(0.8 \mathrm{~g}$ protein $/ \mathrm{kg} / \mathrm{day})$ during $10 \%$ weight loss over 27 weeks (32). In men undertaking arduous military training, a mixed dietary supplement (5.1MJ/day (1220 kcal/day); 45\% carbohydrate, 40\% fat, 15\% protein) prevented $2 \mathrm{~kg}$ loss in lean mass, over 8 weeks, compared with nonsupplemented controls (33). Despite a 
caloric deficit (indicated by weight loss), our participants maintained total lean mass, with an average protein intake of around $1.6 \mathrm{~g} / \mathrm{kg} /$ day.

Low ambient temperatures induce brown adipose tissue (BAT) thermogenesis, mediated by catecholamine upregulation, acting as a sink for glucose and fatty acid uptake.(34) Adaptive thermogenesis is upregulated by $B-3$ adrenergic receptors, which are expressed in fat but not in muscle.(35) Thus, the cold Antarctic environment could partially explain the high selectivity of substrate.

In mixed sex Norwegian Ranger training involving seven-day food and sleep deprivation, women demonstrated greater fat utilization and glycogen preservation than men, implying greater capacity for endurance exercise.(36) Estrogens appear to be responsible for this substrate dimorphism,(37) while women subjectively claim better patrolling performance than men perhaps because of this metabolic advantage.

In addition to exercise and nutrition, the modest altitude of the expedition environment could have mitigated the loss in lean mass, compared with arduous expeditions at extreme altitudes, where hypobaric hypoxia contributes to loss of lean mass (38). Likewise, insufficient sleep, whether at altitude or as a programmed part of arduous training, could impede absorption of macronutrients and reduces gut readiness for daytime absorption (39), and it could be postulated that preservation of sleep contributed to the maintained total lean mass we observed.

No suppression of metabolic parameters such as thyroid hormones or elevated cortisol were seen during or after the expedition. Lean mass exerts a greater effect on resting metabolic rate and appetite than fat mass (40), and demonstrates a greater bidirectional relationship with androgens, and to a lesser extent estrogens, than fat mass (41). Thus, preservation of total lean mass might mitigate against some of the endocrine sequelae of 
negative energy balance. The decrease in leptin, followed by recovery post-expedition, was more pronounced than the changes we observed in body fat. Cold exposure itself may reduce leptin in women,(42) but this appears to become effective only when cold exposure is sustained.(43) The change in HPG axis function we observed did not correlate with leptin, as has been reported previously.(44)

Dynamic attenuations in LH and sex steroids following an energy deficit may confer immediate survival benefits but may be associated with maladaptive suppression of hormonal axes and reproductive, bone or psychological sequelae if sustained.(2) Luteinizing hormone was relatively suppressed prior to and during the expedition (reflecting hormonal contraception usage), but recovered by post-exercise visit pre-2. There was no change in FSH before, during or after the expedition; this is consistent with studies of overtraining syndrome which generally demonstrate relatively normal FSH levels when LH is suppressed (reviewed in Cadegiani et al. (45)), and laboratory studies of reduced EA, which show normal levels relative to suppression of LH in response (46).

Cortisol reactivity and diurnal salivary cortisol were blunted relative to other studies, and may be an appropriate response to a high intensity of training $(20,21)$. Alternatively, similar responses have been noted in dynamic testing of athletes during dysfunctional overtraining, also associated with elevated basal cortisol (reviewed in Cadegiani et al.) (45). Elevated hair cortisol concentrations are associated with exercise per se; whether the marked elevation during the expedition may represent an overtraining syndrome would be a pertinent question for future studies (27). The response of the HPA axis to central negative feedback is greater than has been described elsewhere $(4,20)$. Yehuda et al. reviewed the use of low-dose dexamethasone suppression in post-traumatic stress disorder (PTSD), showing PTSD was associated with increased central axis sensitivity (4). No suggestion of PTSD was noted from the psychological stress or IES-R assessments 
before or after the expedition, thus this may relate simply to age, fitness and lower volume of distribution of these participants compared with previous studies.

Similar exercise-associated patterns in the HPA and HPG axis were seen following restricted carbohydrate intake with aerobic and resistance activity (average $46 \pm 9.1 \mathrm{MET}$ and $4.7 \pm 0.7$ sessions per week, respectively), in normal BMI women over 20 weeks (47). This regimen achieved a $11.9 \%$ weight loss with unchanged lean mass, and was associated with increased menstrual dysfunction, reduced testosterone, estradiol, free T3 and TSH and unchanged cortisol compared with weight-stable, exercising controls. While the degree of weight loss was similar to the present study, this intervention was achieved primarily through dietary restriction, since the exercise was less intense. The investigators also assessed recovery, demonstrating partial normalization of sex and thyroid hormones and leptin after 18 weeks. As in the current study, mood profile was unaffected by the intervention, which might possibly account for the apparently stable cortisol responsiveness we observed.

Other correlates of overtraining syndrome include sleep deprivation and psychological stress.(48) Psychological stress is a prominent feature of extreme physical endeavor. Therefore, while both stress and reduced EA may be shown to cause reproductive endocrine dysfunction independently, their impact in this context may be synergistic and it may be impossible to draw a distinction between them (1). The expedition required both significant mental and physical exertion, although perceived stress levels were modest through the expedition and anxiety, depression and psychosocial risk factor assessments did not change after the expedition.

It has been suggested the psychological stress of Ranger training results from nutrient and sleep deprivation, which serve to increase the arduousness of many military training formats (6). Sleep deprivation in isolation is associated with elevated evening cortisol, 
flattened cortisol day curve, reduced androgen secretion and higher sympathetic nervous system activity (39). Female sex hormones appear to be protective of the effect of sleep deprivation on cortisol blunting after psychosocial stress (49). The sustained moderate to high exercise intensity needed for a polar traverse represents a different form of exertion compared to US Ranger training, including its sustained, repetitive nature, austere environment, safety concerns and isolation. The stress and physical exertion scores reported during the expedition were consistent with previous arduous expeditions $(17,18)$, while sleep diaries showed significantly longer sleep duration than would be expected in Ranger training $(7,28)$, albeit of low perceived restfulness. Both increased sleep and the sustained, submaximal intensity of exercise could also account for the biological resilience we observed. Together with the nutritional strategy taken, and relatively reduced energy expenditure in women compared with men, these factors might have contributed to mitigating some of the negative psychological effects.

The major strength of our study is the unique nature of the expedition; this likely represents the first opportunity to study a cohort of female participants complete an endeavor of such a prolonged, arduous nature. Mitigating against low EA in women is important, since women appear to be at greater risk of low EA and its consequences than men $(1,2)$. Previous studies of prolonged, arduous training have focused on male cohorts and recovery rates in women have not been studied. Furthermore, the effects of exercise or low EA on the dynamic of the HPA and HPG axes have not previously been studied in either sex.

Limitations to our study include the small number of participants. This is unavoidable on such extreme expeditions; we have attempted to mitigate this by a comprehensive characterization of the participants. The team is larger than any previous female-only transantarctic attempts, increasing the number of women who have skied across the continent from four to $10(17,18)$. Other limitations include the natural limitations of a field 
study, such as four day delay in testing after the expedition. Every effort was made to overcome these using study visits shortly after the expedition arrived in Chile with imaging undertaken as soon as reasonably possible following the participants return to the UK. It was not logistically possible to repeat imaging immediately before and after the expedition, or use the same examiner to perform skinfolds in the UK and Chile, so we used the best feasible measures of body composition. The use of hormonal contraceptives, while representative of real-world hormonal milieu, do limit the interpretation of $\mathrm{LH}$ responses. For logistical and ethical reasons, dynamic tests of the HPA axis at a higher level (e.g. insulin tolerance test, corticotrophin releasing hormone test, desmopressin test) were not possible, however in future studies a maximal or two-bout exercise test could be considered. Calculation of cortisol awakening response would add merit to our study, but was not possible since participants were woken 10 minutes before the first saliva sample taken in the pre- and post-expedition day curves.

In conclusion, no short term adverse effects were demonstrated from an unprecedented, successful transantarctic expedition in women. Cortisol reactivity and pituitary gonadotrophin reactivity were not impaired. We hypothesize these findings related to and pre- and intraexpedition nutrition, sleep provision, on the background of desirable selection characteristics, so that participants did not rate the expedition as subjectively stressful and lean mass was maintained.

\section{Acknowledgments}

The study was funded by an unrestricted grant from the UK Women in Ground Close Combat Review. The funders had no role in the study design. The authors are indebted to the Expedition ICE MAIDEN team for their exemplary participation in a very challenging study. We are grateful to the Wellcome Trust Clinical Research Facility (CRF), and particularly Jo Singleton, and to the Coventry NIHR CRF Human Metabolic Research Unit, University Hospitals Coventry and Warwickshire NHS Trust and the University of 
Warwick, Coventry, UK. We are grateful to Antarctic Logistic Expeditions Ltd. for supporting researchers in Antarctica and Chile. The authors would also like to thank the

Surgeon General, Defence Medical Services and Expedition ICE MAIDEN Higher Management Committee for travel and subsistence costs

\section{Conflicts of interest}

None of the authors has conflicts of interest to declare, including professional relationships with companies or manufacturers who will benefit from the results of the present study. The results of the present study do not constitute endorsement by ACSM. The results of the study are presented clearly, honestly, and without fabrication, falsification, or inappropriate data manipulation.

\section{References.}

Gifford RM, Reynolds RM, Greeves J, Anderson RA, Woods DR. Reproductive dysfunction and associated pathology in women undergoing military training. Journal of the Royal Army Medical Corps. 2017;163(5):301-10.

Mountjoy M, Sundgot-Borgen J, Burke L et al. The IOC consensus statement: beyond the Female Athlete Triad--Relative Energy Deficiency in Sport (RED-S). British journal of sports medicine. 2014;48(7):491-7.

Gibbs JC, Williams NI, De Souza MJ. Prevalence of individual and combined components of the female athlete triad. Medicine and science in sports and exercise. 2013;45(5):98596.

Yehuda R. Current status of cortisol findings in post-traumatic stress disorder. The Psychiatric clinics of North America. 2002;25(2):341- 68, vii. 
Interim report on the health risks to women in ground close combat roles 2016 20160706_ADR006101_Report_Women_in_Combat_WEB-FINAL.PDF. 2016. 65 p.

Hoyt RW, Friedl KE. Field studies of exercise and food deprivation. Current Opinion in Clinical Nutrition \& Metabolic Care. 2006;9(6):685-90.

Nindl BC, Barnes BR, Alemany JA, Frykman PN, Shippee RL, Friedl KE. Physiological consequences of U.S. Army Ranger training. Medicine and science in sports and exercise. 2007;39(8):1380-7.

Henning PC, Scofield DE, Spiering BA et al. Recovery of endocrine and inflammatory mediators following an extended energy deficit. The Journal of clinical endocrinology and metabolism. 2014;99(3):956-64.

Rosengren A, Hawken S, Ounpuu S et al. Association of psychosocial risk factors with risk of acute myocardial infarction in 11119 cases and 13648 controls from 52 countries (the INTERHEART study): case-control study. Lancet. 2004;364(9438):953-62.

Weiss DS. The Impact of Event Scale-Revised. In: JP Wilson, TM Keane editors. Assessing psychological trauma and PTSD: a practitioner's handbook. New York: Guildford Press; 1997, pp. 168-89.

Kroenke K, Spitzer RL, Williams JB. The PHQ-9: validity of a brief depression severity measure. Journal of general internal medicine. 2001;16(9):606-13. 
Wells TS, Horton JL, LeardMann CA, Jacobson IG, Boyko EJ. A comparison of the PRIME-MD PHQ-9 and PHQ-8 in a large military prospective study, the Millennium Cohort Study. Journal of affective disorders. 148(1):77-83.

Campbell-Sills L, Stein MB. Psychometric analysis and refinement of the connor-davidson resilience scale (CD-RISC): Validation of a 10-item measure of resilience. Journal of Traumatic Stress. 2007;20(6):1019-28.

Johnson DC, Polusny MA, Erbes CR et al. Development and initial validation of the Response to Stressful Experiences Scale. Military medicine. 2011;176(2):161-9.

Martinsen M, Holme I, Pensgaard AM, Torstveit MK, Sundgot-Borgen J. The development of the brief eating disorder in athletes questionnaire. Medicine and science in sports and exercise. 2014;46(8):1666-75.

Peric M, Zenic N, Sekulic D, Kondric M, Zaletel P. Disordered eating, amenorrhea, and substance use and misuse among professional ballet dancers: Preliminary analysis. Medycyna pracy. 2016;67(1):21-7.

Kahn PM, Leon GR. Group climate and individual functioning in an all-women Antarctic expedition team. Environment and Behavior. 1994;26(5):669-97.

Atlis MM, Leon GR, Sandal GM, Infante MG. Decision Processes and Interactions During a Two-Woman Traverse of Antarctica. Environment and Behavior. 2004;36(3):402-23.

ISAK. International Standards for Anthropometric Assessment. Underdale, SA, Australia2001. 
Reynolds RM, Walker BR, Syddall HE et al. Altered control of cortisol secretion in adult men with low birth weight and cardiovascular risk factors. The Journal of clinical endocrinology and metabolism. 2001;86(1):pp. 245-50.

Kajantie E, Eriksson J, Barker DJ et al. Birthsize, gestational age and adrenal function in adult life: studies of dexamethasone suppression and ACTH1-24 stimulation. Eur J Endocrinol. 2003;149(6):569-75.

Stalder T, Kirschbaum C. Analysis of cortisol in hair--state of the art and future directions. Brain Behav Immun. 2012;26(7):1019-29.

Levy JC, Matthews DR, Hermans MP. Correct homeostasis model assessment (HOMA) evaluation uses the computer program. Diabetes Care. 1998;21(12):2191-2.

Stirrat LI, Walker JJ, Stryjakowska K et al. Pulsatility of glucocorticoid hormones in pregnancy: Changes with gestation and obesity. Clin Endocrinol (Oxf). 2018;88(4):592600.

Kirschbaum C, Tietze A, Skoluda N, Dettenborn L. Hair as a retrospective calendar of cortisol production-increased cortisol incorporation into hair in the third trimester of pregnancy. Psychoneuroendocrinology. 2009;34(1):32-7.

Miller R, Plessow F, Rauh M, Gröschl M, Kirschbaum C. Comparison of salivary cortisol as measured by different immunoassays and tandem mass spectrometry. Psychoneuroendocrinology. 2013;38(1):50-7. 
Gerber M, Brand S, Lindwall M et al. Concerns regarding hair cortisol as a biomarker of chronic stress in exercise and sport science. Journal of sports science \& medicine. $2012 ; 11(4): 571$.

Friedl KE, Moore RJ, Hoyt RW, Marchitelli LJ, Martinez-Lopez LE, Askew EW. Endocrine markers of semistarvation in healthy lean men in a multistressor environment. Journal of applied physiology (Bethesda, Md. : 1985). 2000;88(5):1820-30.

Murphy NE, Carrigan CT, Karl JP, Pasiakos SM, Margolis LM. Threshold of Energy Deficit and Lower-Body Performance Declines in Military Personnel: A Meta-Regression. Sports Medicine. 2018:1-10.

Cadegiani FA, Kater CE. Body composition, metabolism, sleep, psychological and eating patterns of overtraining syndrome: Results of the EROS study (EROS-PROFILE). Journal of sports sciences. 2018;36(16):1902-10.

Calbet JA, Ponce-González JG, Calle-Herrero JdL et al. Exercise preserves lean mass and performance during severe energy deficit: the role of exercise volume and dietary protein content. Frontiers in physiology. 2017;8:483.

Smith GI, Yoshino J, Kelly SC et al. High-protein intake during weight loss therapy eliminates the weight-loss-induced improvement in insulin action in obese postmenopausal women. Cell reports. 2016;17(3):849-61.

Fortes MB, Diment BC, Greeves JP, Casey A, Izard R, Walsh NP. Effects of a daily mixed nutritional supplement on physical performance, body composition, and circulating anabolic hormones during 8 weeks of arduous military training. Applied physiology, 
nutrition, and metabolism = Physiologie appliquee, nutrition et metabolisme. 2011;36(6):967-75.

Sidossis L, Kajimura S. Brown and beige fat in humans: thermogenic adipocytes that control energy and glucose homeostasis. The Journal of clinical investigation. $2015 ; 125(2): 478-86$.

Krief S, Lönnqvist F, Raimbault S et al. Tissue distribution of beta 3-adrenergic receptor mRNA in man. Journal of Clinical Investigation.

1993;91(1):344-9.

Hoyt RW, Opstad PK, Haugen A-H, DeLany JP, Cymerman A, Friedl KE. Negative energy balance in male and female rangers: effects of $7 \mathrm{~d}$ of sustained exercise and food deprivation. The American journal of clinical nutrition. 2006;83(5):1068-75.

Tarnopolsky MA. Sex differences in exercise metabolism and the role of 17-beta estradiol. Medicine and science in sports and exercise. 2008;40(4):648-54.

Wandrag L, Siervo M, Riley HL et al. Does hypoxia play a role in the development of sarcopenia in humans? Mechanistic insights from the Caudwell Xtreme Everest Expedition. Redox biology. 2017;13:60-8.

Potter GDM, Skene DJ, Arendt J, Cade JE, Grant PJ, Hardie LJ. Circadian Rhythm and Sleep Disruption: Causes, Metabolic Consequences, and Countermeasures. Endocrine Reviews. 2016;37(6):584-608. 
Stubbs RJ, Hopkins M, Finlayson G, Duarte C, Gibbons C, Blundell J. Potential effects of fat mass and fat-free mass on energy intake in different states of energy balance. European journal of clinical nutrition. 2018;72(5):698.

Carson JA, Manolagas SC. Effects of sex steroids on bones and muscles: Similarities, parallels, and putative interactions in health and disease. Bone. 2015;80:67-78.

Ricci MR, Fried SK, Mittleman KD. Acute cold exposure decreases plasma leptin in women. Metabolism: clinical and experimental. 2000;49(4):421-3.

Iwen KA, Wenzel ET, Ott V et al. Cold-induced alteration of adipokine profile in humans. Metabolism: clinical and experimental. 2011;60(3):430-7.

Corr M, De Souza M, Toombs R, Williams N. Circulating leptin concentrations do not distinguish menstrual status in exercising women. Human reproduction. 2011;26(3):685-94.

Cadegiani FA, Kater CE. Hormonal aspects of overtraining syndrome: a systematic review. BMC sports science, medicine and rehabilitation. 2017;9:14.

Loucks AB, Thuma JR. Luteinizing hormone pulsatility is disrupted at a threshold of energy availability in regularly menstruating women. The Journal of clinical endocrinology and metabolism. 2003;88(1):297-311.

Hulmi JJ, Isola V, Suonpää $M$ et al. The effects of intensive weight reduction on body composition and serum hormones in female fitness competitors. Frontiers in physiology. 2017;7:689. 
Meeusen R, Duclos M, Foster C et al. Prevention, diagnosis, and treatment of the overtraining syndrome: joint consensus statement of the European College of Sport Science and the American College of Sports Medicine. Medicine and science in sports and exercise. 2013;45(1):186-205.

Bassett SM, Lupis SB, Gianferante D, Rohleder N, Wolf JM. Sleep quality but not sleep quantity effects on cortisol responses to acute psychosocial stress. Stress (Amsterdam, Netherlands). 2015;18(6):638-44.

Tables, figures and Appendices.

Table $1 . \quad$ Baseline characteristics of participants

Table 2. Biochemical and hormonal parameters at baseline, 4 and 14 days after the ex

Figure 1. Experimental design overview

Figure 2. Anthropometric changes during the expedition.

Figure 3. Dynamic gonadotroph and adrenal cortex function before and after the expedi

Figure 4. Dynamic and monthly average cortisol concentrations

\section{Appendices}

Supplementary table $1 . \quad$ Anthropometric changes during the expedition.

Supplementary table 2. Regional lean, fat and bone mass changes during the expedition

Supplementary table 3. Pre and Post- Expedition psychological testing

Supplementary table $4 . \quad$ Average values from dynamic endocrine function testing

Supplementary box $1 . \quad$ Rationale for basal endocrine marker testing 

Table 1. Characteristics of participants at visit pre-1

\begin{tabular}{|c|c|}
\hline Age, years; median (range) & 32.7 (28.6 to 36.1$)$ \\
\hline \multicolumn{2}{|l|}{ Reproductive characteristics } \\
\hline Age at menarche, years; median (range) & $13(11-16)$ \\
\hline \multicolumn{2}{|c|}{$\begin{array}{l}\text { Levonorgestel } 20 \mathrm{mcg} \text { per } 24 \mathrm{~h} \text { intrauterine device (Mirena } \AA \text { ) only - } 4 \\
(67 \%)\end{array}$} \\
\hline \multicolumn{2}{|c|}{$\begin{array}{l}\text { Mirena } \AA \text { plus ethinylestradiol } 30 \mathrm{mcg} / \text { levonorgestrel } 50 \mathrm{mcg}-1^{*} \\
(17 \%)\end{array}$} \\
\hline \multicolumn{2}{|c|}{68 mg subcutaneous implant (Nexplanon $\AA)-1(17 \%)$} \\
\hline \multicolumn{2}{|l|}{ Body composition } \\
\hline $\begin{array}{l}\text { Body mass, kg } \\
\text { Mean (SD) }\end{array}$ & $72.8(4.00)$ \\
\hline $\begin{array}{l}\text { BMI, } \mathrm{kgm}^{-2} \\
\text { Mean (SD) }\end{array}$ & $24.2(0.97)$ \\
\hline \% fat by DXA, kg & $20.92(2.12)$ \\
\hline
\end{tabular}




\begin{tabular}{|l|l|}
\hline mean (SD) & \multicolumn{1}{|l|}{} \\
\hline Lean mass by DXA, kg & $53.5(3.06)$ \\
\hline Psychological assessments & \\
\hline Several periods of psychological stress & $5(83)$ \\
Mean (SD) & \\
\hline Permanent, psychosocial stress & 0 \\
\hline $\mathrm{N}(\%)$ & $1(17)$ \\
\hline Some periods of psychological stress & \\
$\mathrm{N}(\%)$ & 0 \\
\hline Never experienced psychological stress & 0 \\
$\mathrm{~N}(\%)$ & \\
\hline One or more adverse events & \\
$\mathrm{N}(\%)$ & $\mathrm{N}(67)$ \\
\hline High or severe financial stress & \\
\hline
\end{tabular}




\begin{tabular}{|l|l|}
\hline IES-R & $36(9-52)^{\star *}$ \\
\hline
\end{tabular}

\begin{tabular}{|l|l|}
\hline Median (range) & \\
\hline PHQ-9 & $3(0-11)$ \\
\hline BAI & $11(2-15)$ \\
Median (range) & \\
\hline CDRISC 10 & $34(31-36)$ \\
Median (range) & \\
\hline BEDA-Q & \\
\hline Score & $4(0-6)$ \\
\hline Median (range) & \\
\hline BEDA-Q part B & \\
\hline "Are you trying to lose weight now?" & \\
\hline Yes & 0 \\
\hline N (\%) & \\
\hline
\end{tabular}




\begin{tabular}{|c|l|}
\hline Yes & $3(50)$ \\
$N(\%)$ & \\
\hline
\end{tabular}




\begin{tabular}{|c|c|}
\hline "If so, how many times?" & \\
\hline Number of times $(\mathrm{n}[\%])$ & $3-5(2[33])$ \\
& $>5(1[17])$ \\
\hline
\end{tabular}

Caption. Data are mean (SD) unless otherwise stated.

BEDA-Q brief eating disorders in athletes questionnaire. IES-R Impact of events scale (revised), PHQ-9 adjusted patient health questionnaire 9, BAI Beck Anxiety Inventory, CDRISC10 Connor Davidson Resilience Scale 10, N/A not applicable

* One participant using Mirena ${ }^{\circledR}$ also commenced ethinylestradiol $30 \mathrm{mcg} /$ levonorgestrel $50 \mathrm{mcg}$ once daily immediately prior to expedition until after testing was completed.

${ }^{\star \star}$ Applies to four subjects who experienced a significant event 
Table 2. Biochemical and hormonal parameters at baseline, 4 and 14 days after the expedition.

\begin{tabular}{|c|c|c|c|c|c|c|}
\hline Basal (fasting) variable & $\begin{array}{l}\text { Visit pre } 2 \text { (39 } \\
\text { days } \\
\text { preexpedition) } \\
\text { mean (SD) }\end{array}$ & $\begin{array}{l}\text { Visit post } 1 \\
\text { (Expedition + } \\
4 \text { days mean } \\
(S D)\end{array}$ & $\begin{array}{l}\text { Visit post } 2 \\
\text { (Expedition }+ \\
15 \text { days mean } \\
\text { (SD) }\end{array}$ & $\begin{array}{l}\text { Mean }(95 \% \mathrm{Cl}) \text { difference } \\
\text { visit pre } 2 \text { versus visit post } 1\end{array}$ & $\begin{array}{l}\text { Mean }(95 \% \mathrm{Cl}) \text { difference } \\
\text { visit pre } 2 \text { versus visit post } 2\end{array}$ & $\begin{array}{l}P \\
\text { value }\end{array}$ \\
\hline \multicolumn{7}{|c|}{ Reproductive and HPA axis markers } \\
\hline Estradiol $\mathrm{mmol} / \mathrm{L}$ & $227(176)$ & $163(144)$ & $394(183)$ & $64.3(-156,284)$ & $-168(-427.4,91.7)$ & 0.043 \\
\hline $\begin{array}{l}\mathrm{LH} \\
\mathrm{IU} / \mathrm{L}\end{array}$ & $5.36(2.03)$ & $5.13(3.70)$ & $3.42(1.43)$ & $0.23(-4.15,4.61)$ & $1.94(-1.02,4.91)$ & 0.332 \\
\hline $\begin{array}{l}\mathrm{FSH} \\
\mathrm{IU} / \mathrm{L}\end{array}$ & $5.83(1.09)$ & $5.30(1.36)$ & $3.50(0.48)$ & $0.53(-1.47,2.53)$ & $2.33(-0.82,5.48)$ & 0.161 \\
\hline Androstenedione $\mathrm{mmol} / \mathrm{L}$ & $9.56(2.98)$ & $7.33(2.61)$ & $8.91(2.78)$ & $2.23(0.45,4.01)$ & $0.65(-2.92,4.22)$ & 0.148 \\
\hline Total testosterone $\mathrm{mmol} / \mathrm{L}$ & $1.46(1.56)$ & $0.59(0.81)$ & $0.54(0.4)$ & $0.87(-0.8,2.55)$ & $0.92(-0.39,2.22)$ & 0.178 \\
\hline Dihydrotestosterone $\mathrm{mmol} / \mathrm{L}$ & $2.93(2.12)$ & $2.18(1.24)$ & $1.33(0.78)$ & $0.75(-0.5,1.99)$ & $1.6(-1.09,4.28)$ & 0.182 \\
\hline
\end{tabular}




\begin{tabular}{|l|l|l|l|l|l|l|}
\hline DHEA & $360.24(85.34)$ & $370.37(46.32)$ & $412(42.3)$ & $-10.1(-81.9,61.6)$ & $-52.4(-114,9.62)$ & 0.127 \\
\hline
\end{tabular}

\begin{tabular}{|c|c|c|c|c|c|c|}
\hline $\mathrm{mmol} / \mathrm{L}$ & & & & & & \\
\hline 17- $\mathrm{OH}$ Progesterone $\mathrm{mmol} / \mathrm{L}$ & $3.81(5.04)$ & $1.54(1.51)$ & $7.97(4.53)$ & $2.27(-2.18,6.72)$ & $-4.15(-13.1,4.74)$ & 0.071 \\
\hline $\begin{array}{l}\text { SHBG } \\
\mathrm{nmol} / \mathrm{L}\end{array}$ & $59.5(25.4)$ & $100(53.0)$ & $69.0(25.0)$ & $-40.7(24.6,-104)$ & $13.8(-44.9,25.9)$ & 0.132 \\
\hline $\begin{array}{l}\text { Prolactin } \mathrm{mU} / \mathrm{L} \\
(60 \text { to } 500)\end{array}$ & $338(45)$ & & & & & $\mathrm{N} / \mathrm{A}$ \\
\hline LH:FSH ratio & $1.05(0.22)$ & $0.93(0.32)$ & $1.32(0.57)$ & $0.12(-1.10,1.34)$ & $-0.26(-2.12,1.60)$ & 0.791 \\
\hline $\mathrm{AMH} \mathrm{pmol} / \mathrm{L}$ & $12.2(3.85)$ & $9.44(2.61)$ & & $2.79(-1.38,6.97)$ & & 0.147 \\
\hline Cortisol (unsuppressed) $\mathrm{mmol} / \mathrm{L}$ & $552(67.3)$ & $434(74.2)$ & $519(19.4)$ & $117(-123,358)$ & $32.2(-122,186)$ & 0.279 \\
\hline $\begin{array}{l}\text { Cortisol (suppressed by } 0.25 \mathrm{mg} \\
\text { dexamethasone } 10 \text { hours before) } \mathrm{mmol} / \mathrm{L}\end{array}$ & $73.3(45.2)$ & $61.7(33.1)$ & $54.4(11.7)$ & $11.6(-28.1,51.3)$ & $18.8(-5.21,42.9)$ & 0.302 \\
\hline Basal metabolic and nutritional markers & & & & & & \\
\hline
\end{tabular}




\begin{tabular}{|c|c|c|c|c|c|c|}
\hline Albumin $\mathrm{g} / \mathrm{L}$ & $35.4(2.06)$ & $33.1(0.84)$ & $34.9(1.58)$ & $0.94(-0.14,4.71)$ & $0.92(-1.88,2.84)$ & 0.075 \\
\hline Glucose $\mathrm{mmol} / \mathrm{L}$ & $4.93(0.62)$ & $\begin{array}{l}4.57 \\
(0.25)\end{array}$ & $\begin{array}{l}4.42 \\
(0.75)\end{array}$ & $0.37(-0.2,0.97)$ & $0.52(-0.2,1.19)$ & 0.132 \\
\hline
\end{tabular}

\begin{tabular}{|c|c|c|c|c|c|c|}
\hline \multicolumn{7}{|l|}{ HOMA } \\
\hline$\% B$ & $96.4(27.8)$ & $114(39.6)$ & $118(63.0)$ & $15.8(-59.1,22.5)$ & $21.6(-77.1,34.0)$ & 0.634 \\
\hline$\% S$ & $113(31.3)$ & $130(82.2)$ & $140(39.5)$ & $42.8(-127,92.8)$ & $18.5(-75.3 .19 .8)$ & 0.712 \\
\hline IR & $0.94(0.24)$ & $1.00(0.46)$ & $0.76(0.22)$ & $0.26(-0.74,0.62)$ & $0.10(-0.08,0.43)$ & 0.537 \\
\hline Leptin $\mathrm{ng} / \mathrm{mL}$ & $10.8(4.84)$ & $2.71(1.57)$ & $4.93(3.58)$ & $8.09(3.64,12.5)$ & $5.87(1.04,10.7)$ & $0.002^{*}$ \\
\hline IGF-1 $\mathrm{ng} / \mathrm{mL}$ & $46.0(18.8)$ & $29.1(11.9)$ & $46.0(18.8)$ & $33.1(-44.4,110)$ & $-19.5(-79.3,40.3)$ & 0.116 \\
\hline Iron $\mu \mathrm{mol} / \mathrm{L}$ & $23.3(6.05)$ & $28.3(8.87)$ & $19.0(4.29)$ & $2.50(-11.4,1.43)$ & $1.76(-0.20,8.87)$ & 0.091 \\
\hline Ferritin $\mathrm{ng} / \mathrm{mL}$ & $59.7(22.8)$ & $55.3(35.3)$ & $55.2(26.7)$ & $4.33(-11.1,19.8)$ & $4.50(-14.6,23.6)$ & 0.801 \\
\hline TSH $\mathrm{mU} / \mathrm{L}$ & $2.51(0.57)$ & $3.53(1.84)$ & & $-1.02(-2.69,0.66$ & & 0.180 \\
\hline
\end{tabular}




\begin{tabular}{|l|l|l|l|l|l|l|}
\hline Total T3 nmol/L & $1.43(0.08)$ & $1.42(0.09)$ & $1.38(0.07)$ & $-0.17(-0.40,0.37)$ & $0.05(-0.20,0.30)$ & 0.924 \\
\hline Free T4 pmol/L & $12.5(0.34)$ & $11.8(0.54)$ & & $0.67(-0.42,1.75)$ & 0.181 \\
\hline Zinc $\mathrm{gg} / \mathrm{dL}$ & $134(6.15)$ & $122(12.3)$ & $137(15.7)$ & $5.60(-1.91,26.9)$ & $4.31(-13.7,8.41)$ & \\
\hline Urea & $4.53(0.65)$ & $5.37(1.07)$ & $4.63 \quad(0.9)$ & $-0.83(-1.7,0.05)$ & $-0.1(-1,0.81)$ & 0.041 \\
\hline
\end{tabular}

\begin{tabular}{|c|c|c|c|c|c|c|}
\hline $\mathrm{mmol} / \mathrm{L}$ & & & & & & \\
\hline Sodium $\mathrm{mmol} / \mathrm{L}$ & $141(10.2)$ & $143(8.04)$ & $139(5.09)$ & $-2.67(-15.1,9.73)$ & $1.17(-9.5,11.84)$ & 0.822 \\
\hline Potassium $\mathrm{mmol} / \mathrm{L}$ & $4.27(0.34)$ & $\begin{array}{l}4.45 \\
(0.24)\end{array}$ & $\begin{array}{l}4.08 \\
(0.33)\end{array}$ & $-0.18(-0.4,0.05)$ & $0.18(-0.4,0.74)$ & 0.144 \\
\hline Magnesium $\mathrm{mmol} / \mathrm{L}$ & $0.79(0.06)$ & $0.81(0.04)$ & $0.80(0.73)$ & $0.02(-0.06,0.17)$ & $0.01(-0.04,0.25)$ & 0.360 \\
\hline Chloride $\mathrm{mmol} / \mathrm{L}$ & $\begin{array}{l}105.17 \\
(6.97)\end{array}$ & $\begin{array}{l}107.5 \\
(5.01)\end{array}$ & $\begin{array}{l}103.83 \\
(3.19)\end{array}$ & $-2.33(-10.3,5.65)$ & $1.33(-5.3,7.93)$ & 0.381 \\
\hline Creatinine $\mu \mathrm{mol} / \mathrm{L}$ & $63.7 \quad(5.89)$ & $63.3(3.98)$ & $69.0(5.66)$ & $0.33(-4.8,5.42)$ & $-5.33(-9.9,-0.8)$ & 0.023 \\
\hline
\end{tabular}




\begin{tabular}{|l|l|l|l|l|l|}
\hline $\begin{array}{l}\text { Creatine kinase } \\
\mathrm{U} / \mathrm{L}\end{array}$ & $130(16.94)$ & 137 (33.2) & $153(71.8)$ & $77.3(-145.6,300)$ & $-118(-371,134)$ \\
\hline Lactate mmol/L & $0.75(0.17)$ & $\begin{array}{l}0.85 \\
(0.25)\end{array}$ & $\begin{array}{l}0.57 \\
(0.12)\end{array}$ & $-0.1(-0.4,0.17)$ & $0.04(-0.4,0.44)$ \\
\hline $\mathrm{pH}$ & $7.43(0.05)$ & $\begin{array}{l}7.35 \\
(0.01)\end{array}$ & $\begin{array}{l}7.40 \\
(0.01)\end{array}$ & $-0.02(-0.3,0.24)$ & $-0.08(-0.4,0.19)$ \\
\hline Calcium (adjusted) mmol/L & $2.56(0.08)$ & $2.55(0.06)$ & $2.56(0.04)$ & $0.01(-0.06,0.09)$ & 0.491 \\
& & & & & $0.01(-0.11,-0.01)$ \\
\hline
\end{tabular}




\begin{tabular}{|c|c|c|c|c|c|c|}
\hline $25 \mathrm{OH} \mathrm{D}$ & $112(25.3)$ & $75.8(21.3)$ & & $35.8(14.3,57.4)$ & & $0.008^{*}$ \\
\hline Phosphate $\mathrm{mmol} / \mathrm{L}$ & $1.19(0.05)$ & $1.08(0.04)$ & $1.34(0.09)$ & $0.07(-0.06,0.29$ & $0.01(-0.35,0.025)$ & 0.017 \\
\hline
\end{tabular}

Caption. AMH, antimüllerian hormone; DHEA, Dehydroepiandrosterone; $\beta C T X$, $\beta$-carboxyl-terminal cross-linked telopeptide of type I collagen; P1NP Amino-terminal propeptide of type 1 procollagen; FSH, follicle stimulating hormone; HPA, hypothalamic-pituitary-adrenal; HOMA, homeostatic modelling assessment; IGF-1 insulin-like growth factor 1; \%S insulin sensitivity; \%B -beta cell function; -IR- insulin resistance; LH, Luteinizing hormone; T3, triiodothyronine; T4, thyroxine; TSH, thyroid stimulating hormone; 25 OH D 25 hydroxyl vitamin D. P value for repeated measures ANOVA. * denotes statistical significance after Bonferroni adjustment: $p<0.005$ for reproductive markers, $p<0.05$ for cortisol, $\mathrm{p}<0.002$ for metabolic and nutritional markers. 


\section{Figure captions.}

Figure 1. Overview of experimental design and expedition

A

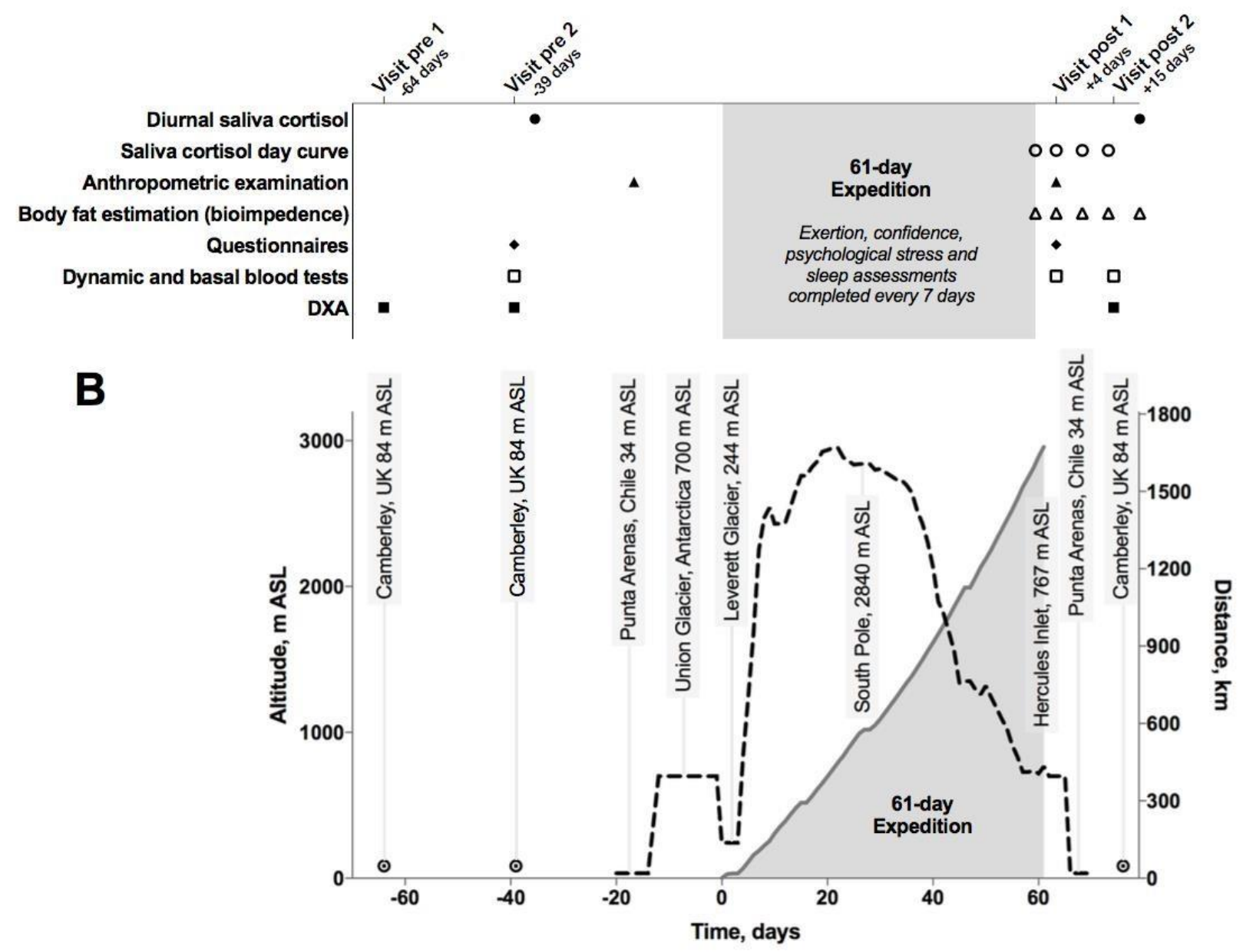

A. Timeline summary of major investigations. Saliva cortisol: 5-point day curve was measured 40-

34 days pre- and 18-24 days post-expedition (filled circle); morning and evening sampling undertaken 1, 5 and 10 days post-expedition (unfilled circle).

Anthropometric examination: weight and skinfolds were undertaken 16 days pre- and 5 days post-expedition (filled triangle). Body fat was estimated by bioimpedance 1,5,10 and 20 days post-expedition (unfilled triangle). Questionnaires were undertaken 39 days pre- and 5 days postexpedition (diamond). Dynamic and basal blood tests: fasted blood sampling and dexamethasone-suppressed combined $\mathrm{GnRH}$ and $\mathrm{ACTH}-(1-24)$ test, 39 days pre, and 4-5 and 15-16 days post-expedition (unfilled square). Body composition measured by DXA scan 64 and 
39 days pre and 15 days post-expedition (filled square). B: Altitude profile of study. Dashed line: altitude. Solid line: elapsed ski distance. Target icons indicate altitude of study visits in Camberley, UK. GnRH, gonadotrophin releasing hormone; ACTH adrenocorticotrophic hormone, DXA dual-energy x-ray absorptiometry, ASL above sea level 
Figure 2. Anthropometric changes during the expedition.

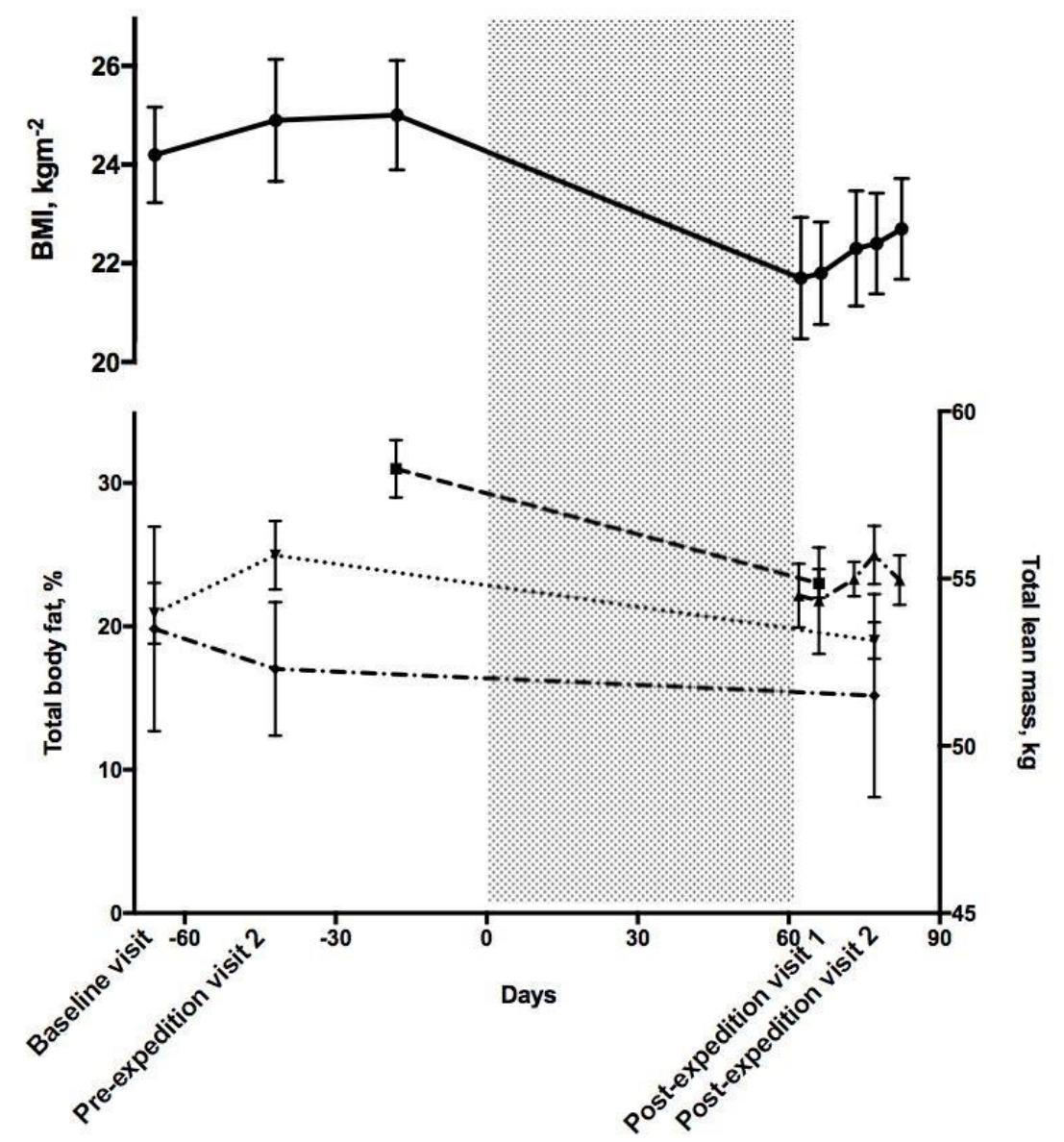

Data are mean \pm SD. Shaded rectangle: Duration of expedition. Circle with solid line: BMI.

Square with dashed: total body fat (\%) by skinfold. Triangle pointing upwards with dash-dotdot line: total body fat (\%) by bio-electrical impedance. Triangle pointing downwards with dotted line: Total body fat (\%) by dual energy $x$-ray absorptiometry. Diamond with dash-dot line: total lean mass $(\mathrm{kg})$ by dual energy $\mathrm{x}$-ray absorptiometry. BMI, body mass index 
Figure 3. Dynamic gonadotrophin function before and after the expedition.

\section{FSH}
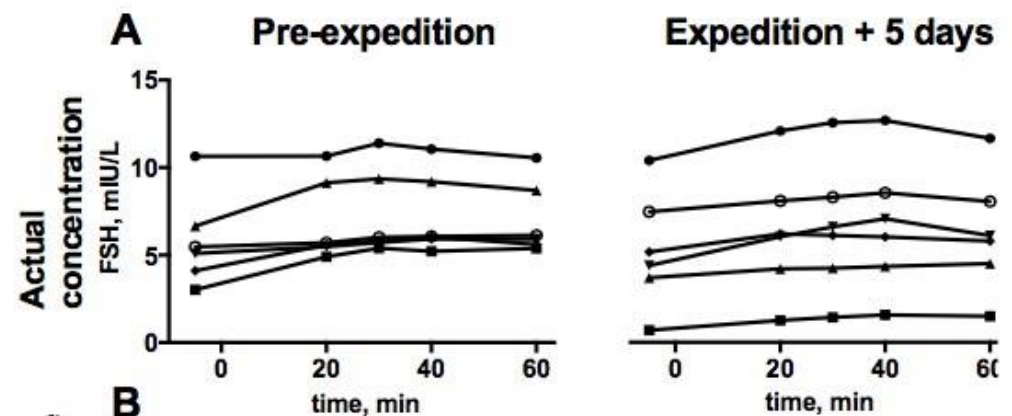

Expedition +16 days
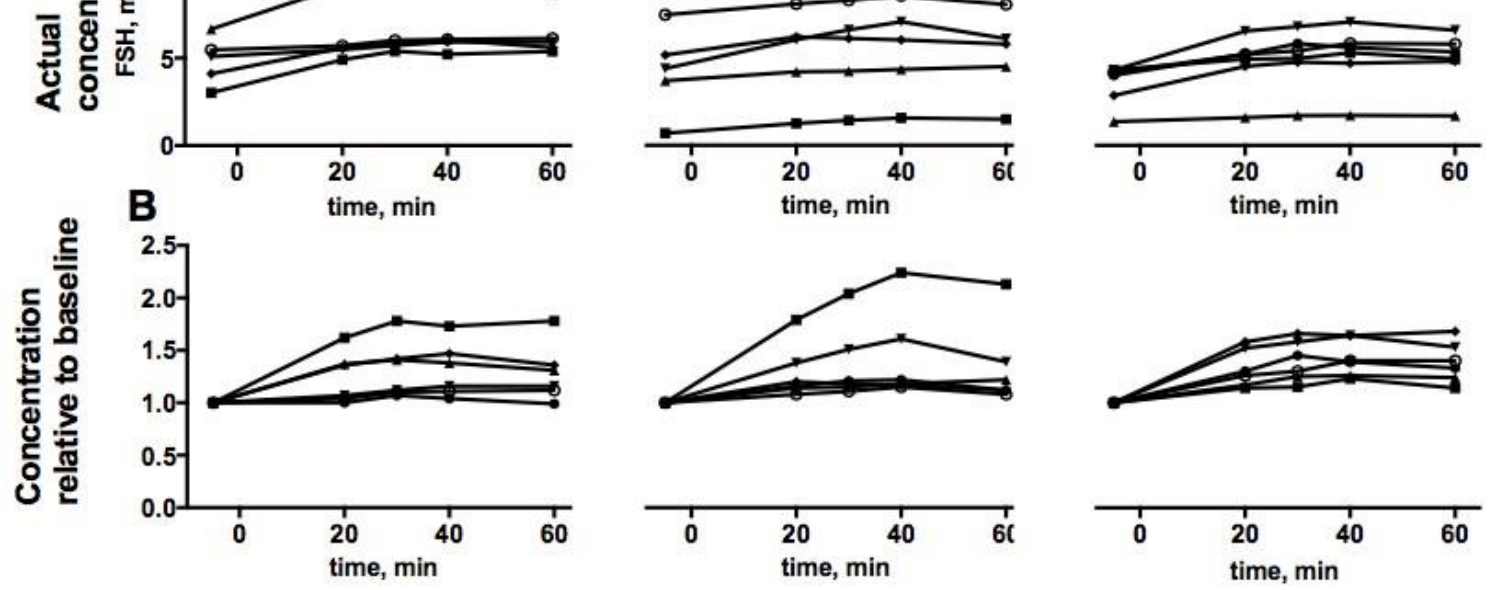

\section{C}

\section{LH}
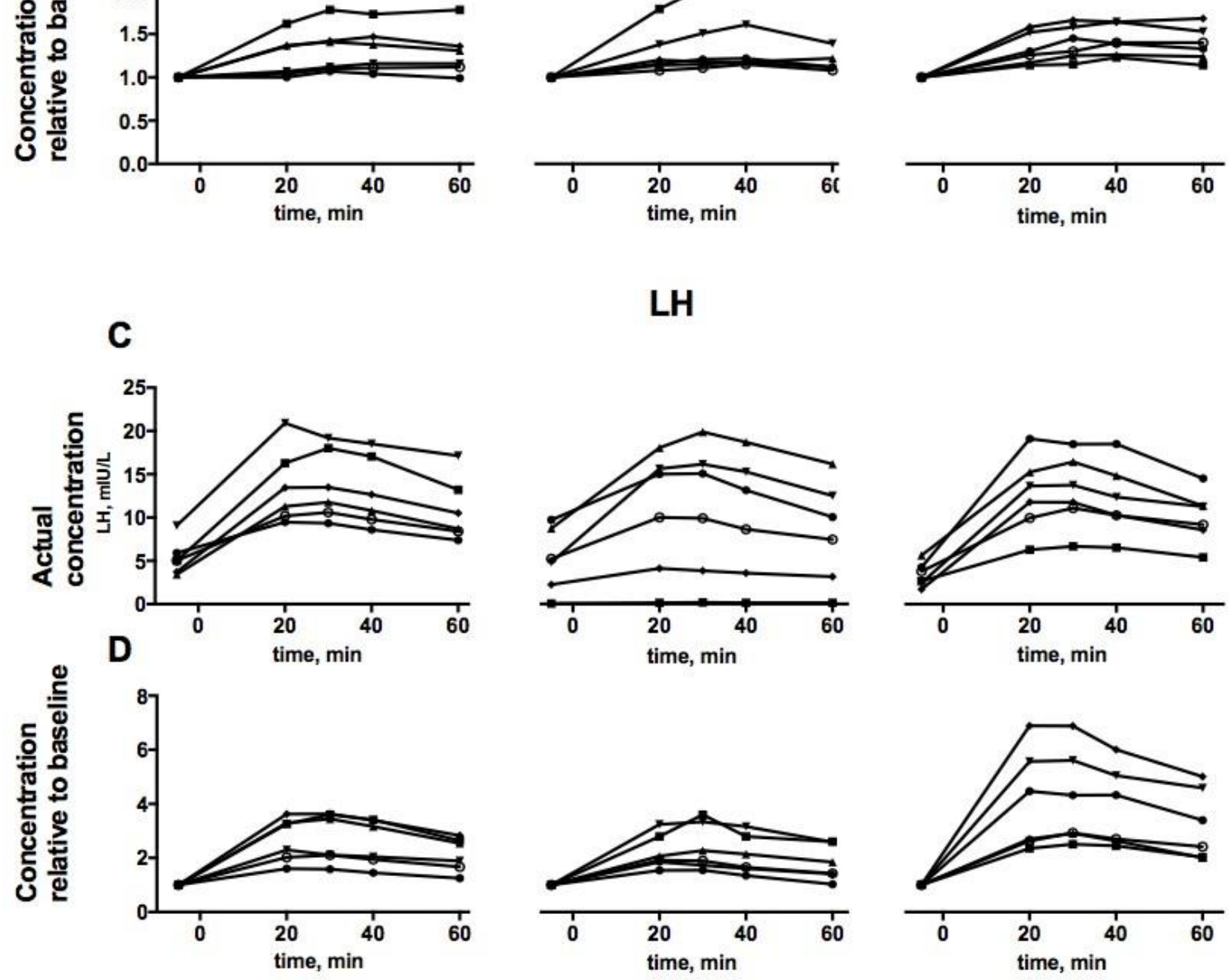

Individuals represented by symbols. Actual concentrations (top row) and fold difference from baseline concentrations (middle row) after $10 \mu \mathrm{g} \mathrm{GnRH}$ administration before, 5 and 16 days after the expedition for FSH (A) and LH (B). The bottom row shows change in AUC and peak concentrations following $10 \mu \mathrm{g} \mathrm{GnRH}$ administration at the same 3 time points for $\mathrm{FSH}(\mathrm{C})$ and $\mathrm{LH}$ 
(D). FSH AUC fold rise and peak fold rise did not change across visits ( $p=0.71$ and $p=0.55$, respectively). There was an upward trend in LH AUC fold rise and peak fold rise ( $p=0.055$ and $\mathrm{p}=0.071$, respectively). $\mathrm{FSH}$, follicle stimulating hormone; $\mathrm{LH}$, luteinizing hormone; $\mathrm{GnRH}$, gonadotrophin releasing hormone; AUC, area under the curve. One individual (filled square) commenced levonogestrel $150 \mathrm{mcg} /$ ethinylestradiol $30 \mathrm{mcg}$ immediately prior to the expedition. One individual (unfilled circle) used Nexplanon $\AA^{\circledR}$ contraceptive implant while all others used a Mirena $\AA^{\circledR}$ intrauterine device 
Figure 4. Dynamic, monthly average hair and diurnal saliva cortisol concentrations
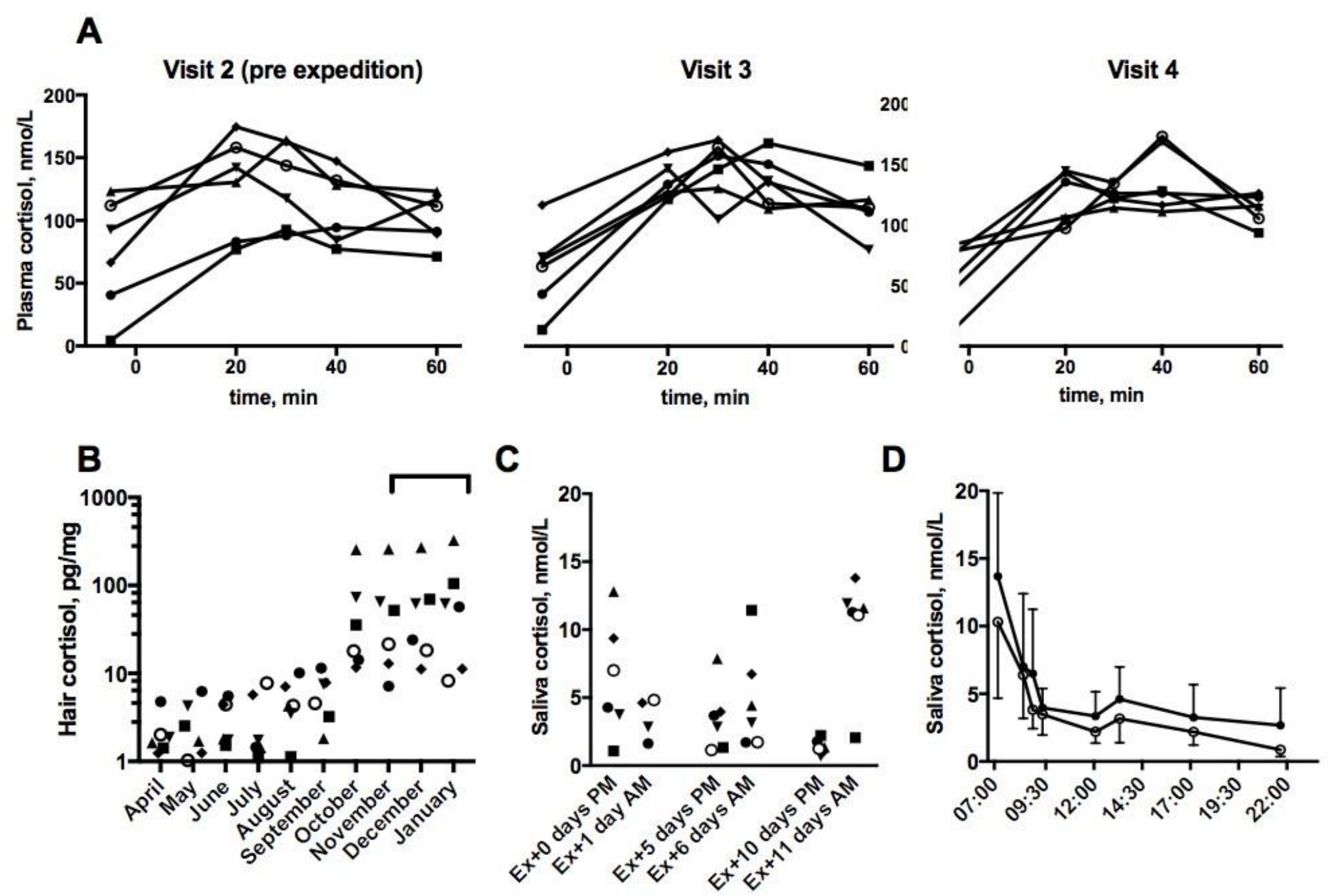
A: adrenal response to (1-24) adrenocorticotrophin, 10 hours after central suppression with $0.25 \mathrm{mg}$ dexamethasone, before, and 5 days and 16 days after the expedition. Top row: cortisol concentrations. Bottom row: fold difference in cortisol from baseline. Area under the curve and peak cortisol did not change between the three time points $(p=0.12$ and $p=0.45$, respectively, figure $4 B)$. $B$ : average monthly cortisol from $1 \mathrm{~cm}$ hair segments prior to and during the expedition (expedition represented by bracket). C: change in AUC and peak concentrations during the dynamic test before, and 5 and 16 days after the expedition. D: Saliva cortisol 36-40 days pre-expedition and 18-24 days post expedition (left panel) and diurnal cortisol 1,4 and 10 days post-expedition (right panel).

Individuals represented by symbols. Time: after ACTH-(1-24) administered. ACTH, adrenocortiocotrophin; $F$, cortisol. ${ }^{* *} \mathrm{p}<0.001$ 
Supplementary table 1. Anthropometric changes during the expedition.

\begin{tabular}{|c|c|c|c|c|c|c|c|c|}
\hline & \multicolumn{3}{|c|}{ Pre-expedition } & \multicolumn{5}{|c|}{ Post-expedition } \\
\hline & $\begin{array}{l}\text { Visit pre-1 } \\
\text { (-64 days) }\end{array}$ & $\begin{array}{l}\text { Visit pre-2 } \\
\text { (-39 days) }\end{array}$ & - 16 days & +1 day & $\begin{array}{l}\text { Visit post- } \\
1 \\
\text { (+5 days) }\end{array}$ & + 10 days & $\begin{array}{l}\text { Visit post-2 } \\
(+15 \text { days })\end{array}$ & $\begin{array}{l}+18 \text { to } 24 \\
\text { days }\end{array}$ \\
\hline $\begin{array}{l}\text { BMI, } \mathrm{kgm}^{-2} \\
\text { Mean (SD) [range] }\end{array}$ & $\begin{array}{l}24.2(0.97) \\
{[22.8-25.45]}\end{array}$ & $\begin{array}{l}24.9(1.24) \\
{[23.11-} \\
26.72]\end{array}$ & $\begin{array}{l}25.0(1.11) \\
{[23.48-} \\
26.73]\end{array}$ & $\begin{array}{l}21.7(1.23) \\
{[19.68-} \\
22.91]\end{array}$ & $\begin{array}{l}22.3(1.03) \\
{[20.59-} \\
23.27]\end{array}$ & $\begin{array}{l}22.3(1.17) \\
{[20.37-} \\
23.53]\end{array}$ & $\begin{array}{l}22.4(1.02) \\
{[20.56-} \\
23.42]\end{array}$ & $\begin{array}{l}22.7(1.02) \\
{[20.81-} \\
23.72]\end{array}$ \\
\hline $\begin{array}{l}\text { Body mass, kg } \\
\text { Mean (SD) [range] }\end{array}$ & $\begin{array}{l}70.47(4.51) \\
{[62.7-74.2]}\end{array}$ & $\begin{array}{l}72.6(1.75) \\
{[65.85-} \\
76.83]\end{array}$ & $\begin{array}{l}72.8(3.99) \\
{[65.8-} \\
77.2]\end{array}$ & $\begin{array}{l}63.2(4.74) \\
{[55.5-} \\
68.4]\end{array}$ & $\begin{array}{l}64.9(4.20) \\
{[58.0-} \\
69.2]\end{array}$ & $\begin{array}{l}65.0(4.03) \\
{[58.4-} \\
68.9]\end{array}$ & {$\left[\begin{array}{l}65.3(4.21) \\
{[58.3-69.1]}\end{array}\right.$} & {$\left[\begin{array}{l}66.2(4.11) \\
{[59.5-69.7]}\end{array}\right.$} \\
\hline$\%$ fat, DXA mean (SD) & $\begin{array}{l}20.92(2.12) \\
{[19.2 \text { to }} \\
25.4]\end{array}$ & $\begin{array}{l}24.97(2.39) \\
{[23.3 \text { to }} \\
30.3]\end{array}$ & & & & & $\begin{array}{l}19.02(1.28) \\
{[17.2 \text { to }} \\
20.4]\end{array}$ & \\
\hline
\end{tabular}




\begin{tabular}{|c|c|c|c|c|c|c|c|c|}
\hline \%fat, BIA mean (SD) & & & & $\begin{array}{l}22.15 \\
(2.22) \\
{[19.4-} \\
26.0]\end{array}$ & $\begin{array}{l}21.8(3.71) \\
{[18.1-} \\
28.8]\end{array}$ & $\begin{array}{l}23.3(1.20) \\
{[22.5-} \\
25.7]\end{array}$ & $25.0(2.04)$ & $\begin{array}{l}23.2(1.74) \\
{[22.2-28.1]}\end{array}$ \\
\hline $\begin{array}{l}\text { Total body mass, DXA, kg } \\
\text { Mean (SD) [range] }\end{array}$ & $\begin{array}{l}70.6(4.5) \\
{[62.68 \text { to }} \\
74.26]\end{array}$ & $\begin{array}{l}72.6(3.9) \\
{[65.85 \text { to }} \\
76.83]\end{array}$ & & & & & $\begin{array}{l}66.4(4.2) \\
{[59.67 \text { to }} \\
70.76]\end{array}$ & \\
\hline $\begin{array}{l}\text { Total lean mass, DXA, kg } \\
\text { Mean (SD) [range] }\end{array}$ & $\begin{array}{l}53.5(3.06) \\
{[48.81 \text { to }} \\
57.27]\end{array}$ & $\begin{array}{l}52.3(2.00) \\
{[48.85 \text { to }} \\
54.72]\end{array}$ & & & & & $\begin{array}{l}51.5(3.04) \\
{[47.25 \text { to }} \\
54.24]\end{array}$ & \\
\hline $\begin{array}{l}\text { Total bone mineral content, } \\
\text { DXA, kg } \\
\text { Mean (SD) [range] }\end{array}$ & $\begin{array}{l}2.75(0.13) \\
{[2.62 \text { to }} \\
2.97]\end{array}$ & $\begin{array}{l}2.80(0.13) \\
{[2.67 \text { to }} \\
3.02]\end{array}$ & & & & & $\begin{array}{l}2.77(0.12) \\
{[2.64 \text { to }} \\
2.97]\end{array}$ & \\
\hline
\end{tabular}


BMI, body mass index. DXA, dual x-ray absorptiometry; BIA, bio-electrical impedance. 
Supplementary table 2.

Regional lean, fat and bone mass changes during the expedition

\begin{tabular}{|c|c|c|c|}
\hline & Visit pre-1 & Visit pre-2 & Visit post-1 \\
\hline \multicolumn{4}{|c|}{ Lean mass $(\mathrm{kg})$} \\
\hline Arms & $5.44(0.57)$ & $5.15(0.45)^{*}$ & $4.99(0.36)$ \\
\hline Legs & $18.79(1.05)$ & $18.08(0.98)^{*}$ & $16.98(1.22)^{*}$ \\
\hline Trunk & $26.15(1.96)$ & $26.06(1.5)$ & $26.52(1.84)$ \\
\hline Android & $3.52(0.24)$ & $8.33(0.61)^{*}$ & $53.57(3.06)$ \\
\hline Gynoid & $3.73(0.25)$ & $8.4(0.59)$ & $52.34(1.99)$ \\
\hline Total & $3.67(0.31)$ & $8.22(0.54)$ & $51.55(3.04)$ \\
\hline \multicolumn{4}{|c|}{ Fat mass $(\mathrm{kg})$} \\
\hline Arms & $1.44(0.12)$ & $1.94(0.16)^{*}$ & $1.49(0.19)^{*}$ \\
\hline Legs & $6.4(1.13)$ & $7.26(1.47)^{*}$ & $5.05(0.79)^{*}$ \\
\hline Trunk & $5.59(1.09)$ & $7.47(1.16)^{*}$ & $4.79(0.66)^{*}$ \\
\hline Android & $0.61(0.17)$ & $0.9(0.15)^{*}$ & $0.49(0.08)^{*}$ \\
\hline Gynoid & $2.92(0.52)$ & $3.71(0.59)^{*}$ & $2.49(0.43)^{*}$ \\
\hline Total & $14.23(2.11)$ & $17.5(2.52)^{*}$ & $12.13(1.37)^{*}$ \\
\hline Total (\%) & $1.44(0.12)$ & $1.94(0.16)^{*}$ & $1.49(0.19)^{*}$ \\
\hline \multicolumn{4}{|c|}{ Bone mineral content $(\mathrm{kg})$} \\
\hline Arms & $0.34(0.02)$ & $0.35(0.03)$ & $0.35(0.03)$ \\
\hline Legs & $1.05(0.06)$ & $1.05(0.06)$ & $1.05(0.05)$ \\
\hline Trunk & $0.83(0.07)$ & $0.86(0.07)^{*}$ & $0.83(0.07)$ \\
\hline
\end{tabular}




\begin{tabular}{|l|l|l|l|}
\hline Android & $0.05(0.00)$ & $0.06(0.01)^{*}$ & $0.05(0.01)$ \\
\hline Gynoid & $0.30(0.02)$ & $0.30(0.02)^{*}$ & $0.30(0.02)$ \\
\hline Total & $2.75(0.13)$ & $2.80(0.13)^{*}$ & $2.77(0.12)$ \\
\hline
\end{tabular}

Android: the area between the ribs and pelvis, gynoid: pelvis and upper thighs.

${ }^{*} p<0.05$ vs previous visit (paired t test) 
Supplementary table 3 Comparison of Pre and Post- Expedition psychological testing

\begin{tabular}{|c|c|c|c|}
\hline & Score Pre & $\begin{array}{l}\text { Score Post ('during } \\
\text { expedition') }\end{array}$ & $p$ \\
\hline $\begin{array}{l}\text { Several periods of } \\
\text { psychological stress }\end{array}$ & 5 & 2 & 0.079 \\
\hline $\begin{array}{l}\text { Permanent psychosocial } \\
\text { stress }\end{array}$ & 0 & 0 & 1.0 \\
\hline $\begin{array}{l}\text { Some periods of } \\
\text { psychological stress }\end{array}$ & 1 & 3 & 0.2 \\
\hline $\begin{array}{l}\text { Never experienced } \\
\text { psychological stress }\end{array}$ & 0 & 1 & 1 \\
\hline $\begin{array}{l}\text { One or more adverse } \\
\text { events }\end{array}$ & 4 & 1 & 0.079 \\
\hline $\begin{array}{l}\text { High or severe financial } \\
\text { stress }\end{array}$ & 0 & 0 & 1.0 \\
\hline $\begin{array}{l}\text { IES-R } \\
\text { Median (range) }\end{array}$ & $36(9-52)^{*}$ & $41^{* *}$ & $\mathrm{~N} / \mathrm{A}$ \\
\hline $\begin{array}{l}\text { PHQ-9 } \\
\text { Median (range) }\end{array}$ & $3(0-11)$ & $4(1-6)$ & 1.0 \\
\hline $\begin{array}{l}\text { BAI } \\
\text { Median (range) }\end{array}$ & $11(2-15)$ & $6(2-11)$ & 0.386 \\
\hline $\begin{array}{l}\text { CDRISC } 10 \\
\text { Median (range) }\end{array}$ & $34(31-36)$ & $31(29-35)$ & 0.076 \\
\hline BEDA-Q & & & \\
\hline
\end{tabular}




\begin{tabular}{|c|l|l|l|}
\hline Score & $4(0-6)$ & $7(2-8)$ & 0.009 \\
Median (range) & & & \\
\hline
\end{tabular}




\begin{tabular}{|l|l|l|l|}
\hline BEDA-Q part B & \multicolumn{2}{|l|}{} & \\
\hline \multicolumn{2}{|l|}{ “Are you trying to lose weight now?" } & $1(16.7)$ & 1.00 \\
\hline Yes n (\%) & $0(0.0)$ & & \\
\hline “Have you ever tried to lose weight?" & $4(66.7)$ & 0.558 \\
\hline Yes n (\%) & 3 (50) & \\
\hline "If so, how many times?" & & $3-5(2)$ & \\
\hline & $3-5(2)$ & $>5(1)$ & \\
& $>5(1)$ & $>1(1)$ & \\
& & 3 & \\
\hline
\end{tabular}

BEDA-Q: brief eating disorders in athletes questionnaire, IES-R: Impact of events scale (revised), PHQ-9 adjusted patient health questionnaire 9, BAI Beck Anxiety Inventory, CDRISC10 Connor Davidson Resilience Scale 10, N/A not applicable

* Applies to four subjects who experienced a significant event

${ }^{\star *}$ Applies to one subject who experienced a significant event 
Supplementary table 4. Mean values for dynamic endocrine function tests

\begin{tabular}{|c|c|c|c|c|c|}
\hline \multicolumn{6}{|c|}{ FSH concentration (figure $3 \mathrm{~A}$ ) } \\
\hline & Baseline & $20 \min$ & $30 \mathrm{~min}$ & $40 \min$ & $60 \min$ \\
\hline Pre-Ex & $5.83(2.66)$ & $6.91(2.38)$ & $7.28(2.49)$ & $7.25(2.33)$ & $7.05(2.1)$ \\
\hline Ex +5 days & $5.3(3.33)$ & $6.31(3.65)$ & $6.55(3.77)$ & $6.71(3.79)$ & $6.27(3.42)$ \\
\hline Ex +16 days & $3.5(1.18)$ & $4.67(1.65)$ & $4.91(1.73)$ & $5.03(1.8)$ & $4.86(1.68)$ \\
\hline \multicolumn{6}{|c|}{ FSH concentration relative to baseline (figure 3B) } \\
\hline Pre-Ex & & $1.24(0.25)$ & $1.32(0.28)$ & $1.31(0.26)$ & $1.29(0.28)$ \\
\hline Ex +5 days & & $1.29(0.26)$ & $1.37(0.36)$ & $1.43(0.44)$ & $1.34(0.4)$ \\
\hline Ex +16 days & & $1.33(0.18)$ & $1.40(0.20)$ & $1.43(0.18)$ & $1.39(0.19)$ \\
\hline \multicolumn{6}{|c|}{ LH concentration (figure 3C) } \\
\hline Pre-Ex & $5.36(2.04)$ & $13.59(4.35)$ & $13.73(4.03)$ & $12.90(4.03)$ & $10.89(3.68)$ \\
\hline Ex +5 days & $5.13(3.70)$ & $10.49(7.10)$ & $10.84(7.63)$ & $9.92(7.12)$ & $8.25(5.95)$ \\
\hline Ex +5 days & $3.42(1.43)$ & $12.67(4.42)$ & $13.03(4.18)$ & $12.12(4.15)$ & $10.04(3.08)$ \\
\hline \multicolumn{6}{|c|}{ LH concentration relative to baseline (figure 3D) } \\
\hline Pre-Ex & & $2.68(0.82)$ & $2.74(0.91)$ & $2.57(0.86)$ & $2.14(0.63)$ \\
\hline Ex +5 days & & $2.24(0.64)$ & $2.40(0.87)$ & $2.12(0.72)$ & $1.82(0.65)$ \\
\hline Ex +5 days & & $4.10(1.86)$ & $4.19(1.75)$ & $3.86(1.49)$ & $3.24(1.31)$ \\
\hline \multicolumn{6}{|c|}{ Cortisol concentration (figure 4A) } \\
\hline Pre-Ex & $73.25(45.23)$ & $127.54(39.77)$ & $128.14(33.82)$ & $110.53(28.95)$ & $100.60(19.9)$ \\
\hline Ex +5 days & $61.66(33.11)$ & $130.53(14.62)$ & $140.09(23.50)$ & $131.77(19.47)$ & $110.16(21.39)$ \\
\hline Ex +5 days & $54.43(28.60)$ & $122.21(21.50)$ & $125.79(8.02)$ & $137.61(26.91)$ & $113.19(12.03)$ \\
\hline
\end{tabular}




\begin{tabular}{|c|c|c|c|c|c|c|c|c|c|c|c|c|c|c|c|c|}
\hline \multicolumn{17}{|c|}{ Hair cortisol by month (figure 4B) } \\
\hline \multirow[t]{2}{*}{ Month* } & Apr & \multicolumn{2}{|c|}{ May } & \multicolumn{2}{|l|}{ Jun } & \multicolumn{2}{|l|}{ Jul } & Aug & Sep & \multicolumn{2}{|c|}{ Oct } & \multicolumn{2}{|l|}{ Nov } & \multicolumn{2}{|c|}{$\mathrm{Dec}$} & Jan \\
\hline & $\begin{array}{l}8.36 \\
(2.89)\end{array}$ & \multicolumn{2}{|c|}{$\begin{array}{l}11.40 \\
(1.78)\end{array}$} & \multicolumn{2}{|c|}{$\begin{array}{l}10.83 \\
(3.43)\end{array}$} & \multicolumn{2}{|l|}{$\begin{array}{l}11.96 \\
(4.89)\end{array}$} & $\begin{array}{l}11.58 \\
(4.68)\end{array}$ & $\begin{array}{l}9.50 \\
(4.94)\end{array}$ & \multicolumn{2}{|c|}{$\begin{array}{l}35.22 \\
(29.31)\end{array}$} & \multicolumn{2}{|c|}{$\begin{array}{l}38.86 \\
(36.2)\end{array}$} & \multicolumn{2}{|c|}{$\begin{array}{l}41.48 \\
(48.56)\end{array}$} & $\begin{array}{l}54.79 \\
(75.41)\end{array}$ \\
\hline \multicolumn{17}{|c|}{ Diurnal Hair cortisol post-Ex (figure 4C) } \\
\hline \multicolumn{2}{|c|}{ Ex+1 day $P M$} & \multicolumn{3}{|c|}{$E x+2$ days $A M$} & \multicolumn{3}{|c|}{ Ex+4 days $P M$} & \multicolumn{3}{|c|}{ Ex +5 days $A M$} & \multicolumn{4}{|c|}{ Ex+10 days $P M$} & \multicolumn{2}{|c|}{ Ex+11 days $A M$} \\
\hline \multicolumn{2}{|c|}{$6.38(4.24)$} & \multicolumn{3}{|c|}{$6.89(7.74)$} & \multicolumn{3}{|c|}{$3.47(2.45)$} & \multicolumn{3}{|c|}{$4.86(3.73)$} & \multicolumn{3}{|c|}{$1.37(0.55)$} & & \multicolumn{2}{|c|}{$10.29(4.15)$} \\
\hline \multicolumn{17}{|c|}{ Hair cortisol day curve (figure 4D) } \\
\hline Time & $07: 10$ & & $08: 30$ & & 09 & & 09: & & $12: 15$ & & $13: 30$ & & & $: 20$ & & $21: 50$ \\
\hline Pre-Ex & 13.68 & 16) & $\begin{array}{l}7.03 \\
(5.37\end{array}$ & & 6.4 & $8(4.76)$ & 3.9 & 1.43) & $3.36(1.7$ & & $4.6(2$ & 39) & & $26(2$ & (42) & $\begin{array}{l}2.68 \\
(2.75)\end{array}$ \\
\hline Post-Ex & 10.31 & 63) & 6.39 & (3.2) & 3.8 & $2(1.39)$ & 3.4 & 1.52) & $2.2(0.85$ & & 3.17 & 1.79) & & $18(0$ & $.97)$ & $\begin{array}{l}0.86 \\
(0.50)\end{array}$ \\
\hline
\end{tabular}

Baseline: immediately prior to dynamic function test, $\mathrm{LH}$ : luteinizing hormone, FSH: follicle stimulating hormone, Ex: expedition 


\section{Hormonal markers tested}

$17 \mathrm{OH}$ Progesterone is an important steroid precursor hormone and is elevated in common forms of congenital adrenal hyperplasia $(\mathrm{CAH})$. It is commonly checked to exclude $\mathrm{CAH}$.

Androstenedione is a weak adrenal androgen and precursor of testosterone and estradiol. It is also produced in the ovaries under influence of gonadotrophins and higher levels may predict recovery from FHA. \{falsetti 2002\}

Anti-müllerian hormone is a biomarker of ovarian reserve. It peaks during puberty, then correlates inversely with age from around age 25 years.\{Lie Fong 2012\}

Cortisol is a glucocorticoid produced by the hypothalamic-pituitary-adrenal axis. It has important roles in mobilizing energy stores and may be released in response to external stimuli, such as physical or psychosocial threats or challenges. 
Estradiol is the major feminizing sex hormone, responsible for the development of secondary sexual characteristics. It is produced from estrone or testosterone, predominantly but not exclusively in the ovaries.

Inhibin B is produced in the ovaries in response to $\mathrm{FSH}$ and is reflects early-follicular phase follicle activity.\{McNeilly 2012\}

LH, FSH are secreted in a pulsatile manner by the anterior pituitary in response to $\mathrm{GnRH}$, and serve to control gonad function. The LH:FSH ratio is elevated in conditions with elevated androgen levels, such as polcystic ovarian syndrome.

Prolactin is secreted by the anterior pituitary and is included as part of a complete anterior pituitary function test.

Sex hormone binding globulin is produced by the liver and binds androgens and estrogens, limiting the amount of biologically available hormone. It is produced in response to estrogens while its production is reduced by androgens and IGF-1.

Testosterone is the main androgen, produced in in men and to a lesser extent women. It is activated to dihydrotestosterone, which has higher androgenic effect, by $5 \square$ reductase 